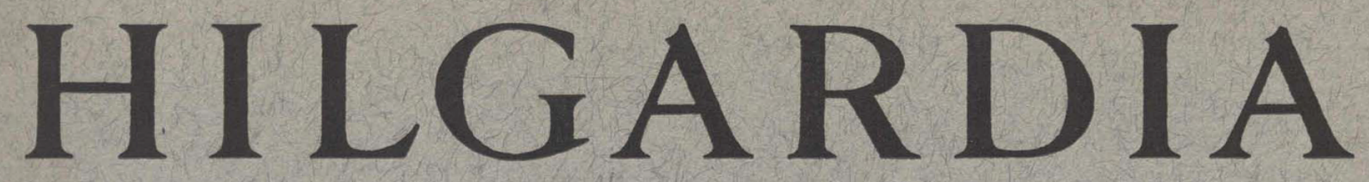

A Journal of Agricultural Science Published by the California Agricultural Experiment Station

\title{
THEORY AND APPLICATION OF FRACTIONAL-BLENDING SYSTEMS
}

G. A. BAKER, M. A. AMERINE, and E. B. ROESSLER 
A theory for calculating proportions of each age and average age of products processed in fractional-blending systems has been developed and applied to several systems for aging wine. The average ages have been calculated in the oldest container of systems of from 4 to 8 barrels after 1 to 50 years of operation for withdrawals of 50,25 , and 10 per cent. The results show that fractional-blending systems produce beverages of a constant average age after varying periods of operation. The average age in the product may be increased by increasing the number of barrels in the system, by decreasing the per cent drawn off each time, or by making withdrawals less frequently. 


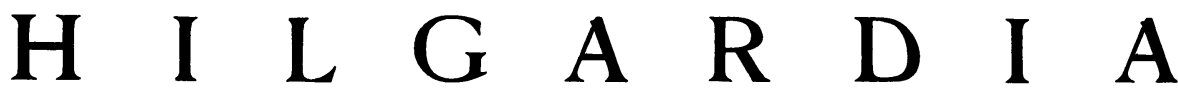

A Journal of Agricultural Science Published by

the California Agricultural Experiment Station

VoL. 21

MAY, 1952

No. 14

\section{THEORY AND APPLICATION OF FRACTIONAL- BLENDING SYSTEMS ${ }^{1}$}

\author{
G. A. BAKER, ${ }^{2}$ M. A. AMERINE, ${ }^{3}$ and E. B. ROESSLER ${ }^{4}$
}

\section{INTRODUCTION}

MANY FOOD products are sold under brand names which are taken as a guarantee of a characteristic type and uniform quality over a period of years. Because of variations due to the season or circumstances under which the product is produced, different lots may have distinct characteristics which are undesirable from the standpoint of marketing under a universal name indicating qualities that are independent of time and place. One obvious way of insuring uniform characteristics of a product is to resort to a blending process of some kind. With many products such as vinegar, alcoholic and certain other beverages, and other products obtained as the result of fermentation and chemical change dependent on time of exposure, fractional blending is effective in maintaining uniformity. A fractional-blending system, as the term is used here, means a mixing process consisting of a partial withdrawal with a corresponding replacement.

Although fractional-blending systems have been in use for many years, those who use them have had only empirical and intuitional knowledge of the effects of varying their structure. In order that such methods of maintaining uniformity of marketed products might be exploited to the full, a study of the underlying mathematical theory was undertaken. The present paper reports the results, in sufficient detail to enable plant managers and research workers to adapt the general theory to their particular needs.

To clarify the way the formulas developed may be used in practical problems, the results are applied to the aging of alcoholic beverages ; but it should be emphasized that the principles of blending are applicable to a wide variety of problems.

\footnotetext{
${ }^{1}$ Received for publication March 10, 1951.

${ }^{2}$ Associate Professor of Mathematics and Associate Statistician in the Experiment Station, Davis.

${ }^{3}$ Associate Professor of Enology and Associate Enologist in the Experiment Station, Davis.

${ }^{4}$ Professor of Mathematics and Statistician in the Experiment Station, Davis.
} 


\section{AGING OF ALCOHOLIC BEVERAGES, ESPECIALLY WINE}

With such wines as port and sherry and with brandy and other spirits, much of the character and quality of the beverage depends on an aging process. Keeping the type and quality uniform from year to year-difficult with any alcoholic beverage-is particularly difficult with them. Hence their producers may well be interested in fractional-blending systems: such systems enable the producer to maintain uniformity in the product more effectively than by any other procedure.

A fractional-blending system, once set up, becomes more valuable with time because the average age of the wine in the oldest barrels increases for many years. On the other hand, it is expensive to set up because it is started with wine of various ages and presupposes continuous operation over a number of years. Furthermore, with wines, it requires close control to prevent contamination and spoilage. No vintner should institute a system of fractional blending unless he has available technical assistants of sufficient skill to handle it without contamination and to detect incipient diseases. With distilled spirits the danger of microbial spoilage does not exist; however, changes in regulations would be required to permit distillers to claim a just age for products of such a system.

Those concerned with honesty in advertising and with law enforcement will wish to know how much wine of various ages there is in the product of such an aging system after given periods of operation. The present theory provides methods for calculating these percentages and for accurately assessing the age of the final product-its average age.

These calculations may also assist producers in choosing a fractionalblending system adapted to their needs. By consulting the tables a producer can select a system to fit the type of handling required (frequency of drawing-off, proportion withdrawn each time), and estimate the amount of aging needed, and the amount he must invest in order to increase uniformity of his product.

\section{THE SOLERA SYSTEM}

In order to apply the results of this study, one must have clearly in mind the general procedure in fractional blending. Perhaps this can best be explained by a brief description of the solera system. This is used for sherry in Spain, mainly to maintain uniformity of the type and quality. Brandy is aged by a similar system in that country. Blending systems of the same general type are also used for Madeira and Marsala wines.

To set up a solera, wines of several ages, but of the same general character, are selected. The amount of wine of each age used depends on the quantity available and on the commercial demand for wine of that particular type. Normally, approximately the same quantity of wine of each age is used. A simple solera at the start might thus consist of 1 to 100 or more containers (called butts in Spain and containing about 130 gallons each) of 4-year-old wine, the same or a similar number of 3-year, 2-year, and 1-year-old wine. This would be a 4-stage or 4-step solera.

In operation, equal amounts of wine are removed from the oldest butts once a year or more often. From 10 to 25 per cent is withdrawn each time. 
This is used for bottling or for blends with other wines. After the wine is drawn off from the oldest butts, these are filled to their original volume from the next younger containers. The latter are then filled from still younger ones up to the end of the series. The youngest containers are filled with wine of the same type, usually of the current production, 0 to 12 months of age.

With the drier types of sherry the solera is drawn on rather frequently and for a fairly large constant portion each time. This is because these types are always aged under a film of yeast and must be kept going ; otherwise the character of the wine may change owing to the yeast's activity. With the sweeter

Table 1

FRACTIONAL-BLENDING SYSTEM WITH THREE BARRELS WITH A DRAWING-OFF PERIOD OF ONE YEAR

\begin{tabular}{|c|c|c|c|c|c|c|c|c|c|c|c|c|}
\hline \multirow{3}{*}{$\begin{array}{l}\text { End of } \\
\text { period }\end{array}$} & \multicolumn{4}{|c|}{ Barrel 1} & \multicolumn{4}{|c|}{ Barrel 2} & \multicolumn{4}{|c|}{ Barrel 3} \\
\hline & \multicolumn{2}{|c|}{ Before drawing } & \multicolumn{2}{|c|}{ After drawing } & \multicolumn{2}{|c|}{ Before drawing } & \multicolumn{2}{|c|}{ After drawing } & \multicolumn{2}{|c|}{ Before drawing } & \multicolumn{2}{|c|}{ After drawing } \\
\hline & Age & Proportion & Age & Proportion & Age & Proportion & Age & Proportion & Age & Proportion & Age & Proportion \\
\hline 1 & 1 & 1 & $\begin{array}{l}0 \\
1\end{array}$ & $\begin{array}{l}p \\
q\end{array}$ & 2 & 1 & $\begin{array}{l}1 \\
2\end{array}$ & $\begin{array}{l}p \\
q\end{array}$ & 3 & 1 & $\begin{array}{l}2 \\
3\end{array}$ & $\begin{array}{l}p \\
q\end{array}$ \\
\hline 2 & $\begin{array}{l}1 \\
2\end{array}$ & $\begin{array}{l}p \\
q\end{array}$ & $\begin{array}{l}0 \\
1 \\
2\end{array}$ & $\begin{array}{l}p \\
p q \\
q^{2}\end{array}$ & $\begin{array}{l}2 \\
3\end{array}$ & $\begin{array}{l}p \\
q\end{array}$ & $\begin{array}{l}1 \\
2 \\
3\end{array}$ & $\begin{array}{l}p^{2} \\
2 p q \\
q^{2}\end{array}$ & $\begin{array}{l}3 \\
4\end{array}$ & $\begin{array}{l}p \\
q\end{array}$ & $\begin{array}{l}2 \\
3 \\
4\end{array}$ & $\begin{array}{l}p^{2} \\
2 p q \\
q^{2}\end{array}$ \\
\hline 3 & $\begin{array}{l}1 \\
2 \\
3\end{array}$ & $\begin{array}{l}p \\
p q \\
q^{2}\end{array}$ & $\begin{array}{l}0 \\
1 \\
2 \\
3\end{array}$ & $\begin{array}{l}p \\
p q \\
p q^{2} \\
q^{3}\end{array}$ & $\begin{array}{l}2 \\
3 \\
4\end{array}$ & $\begin{array}{l}p^{2} \\
2 p q \\
q^{2}\end{array}$ & $\begin{array}{l}1 \\
2 \\
3 \\
4\end{array}$ & $\begin{array}{l}p^{2} \\
2 p^{2} q \\
3 p q^{2} \\
q^{3}\end{array}$ & $\begin{array}{l}3 \\
4 \\
5\end{array}$ & $\begin{array}{l}p^{2} \\
2 p q \\
q^{2}\end{array}$ & $\begin{array}{l}2 \\
3 \\
4 \\
5\end{array}$ & $\begin{array}{l}p^{3} \\
3 p^{2} q \\
3 p q^{2} \\
q^{3}\end{array}$ \\
\hline 4 & $\begin{array}{l}1 \\
2 \\
3 \\
4\end{array}$ & $\begin{array}{l}p \\
p q \\
p q^{2} \\
q^{3}\end{array}$ & $\begin{array}{l}0 \\
1 \\
2 \\
3 \\
4\end{array}$ & $\begin{array}{l}p \\
p q \\
p q^{2} \\
p q^{3} \\
q^{4}\end{array}$ & $\begin{array}{l}2 \\
3 \\
4 \\
5\end{array}$ & $\begin{array}{l}p^{2} \\
2 p^{2} q \\
3 p q^{2} \\
q^{3}\end{array}$ & $\begin{array}{l}1 \\
2 \\
3 \\
4 \\
5\end{array}$ & $\begin{array}{l}p^{2} \\
2 p^{2} q \\
3 p^{2} q^{2} \\
4 p q^{3} \\
q^{4}\end{array}$ & $\begin{array}{l}3 \\
4 \\
5 \\
6\end{array}$ & $\begin{array}{l}p^{3} \\
3 p^{2} q \\
3 p q^{2} \\
q^{3}\end{array}$ & $\begin{array}{l}2 \\
3 \\
4 \\
5 \\
6\end{array}$ & $\begin{array}{l}p^{3} \\
3 p^{3} q \\
6 p^{2} q^{2} \\
4 p q^{3} \\
q^{4}\end{array}$ \\
\hline 5 & $\begin{array}{l}1 \\
2 \\
3 \\
4 \\
5 \\
6\end{array}$ & $\begin{array}{l}p \\
p q \\
p q^{2} \\
p q^{3} \\
q^{4}\end{array}$ & $\begin{array}{r}0 \\
1 \\
2 \\
3 \\
4 \\
5\end{array}$ & $\begin{array}{l}p \\
p q \\
p q^{2} \\
p q^{3} \\
p q^{4} \\
q^{5}\end{array}$ & $\begin{array}{l}2 \\
3 \\
4 \\
5 \\
6\end{array}$ & $\begin{array}{l}p^{2} \\
2 p^{2} q \\
3 p^{2} q^{2} \\
4 p q^{3} \\
q^{4}\end{array}$ & $\begin{array}{l}1 \\
2 \\
3 \\
4 \\
5 \\
6\end{array}$ & $\begin{array}{l}p^{2} \\
2 p^{2} q \\
3 p^{2} q^{2} \\
4 p^{2} q^{3} \\
5 p q^{4} \\
q^{5}\end{array}$ & $\begin{array}{l}3 \\
4 \\
5 \\
6 \\
7\end{array}$ & $\begin{array}{l}p^{3} \\
3 p^{3} q \\
6 p^{2} q^{2} \\
4 p q^{3} \\
q^{4}\end{array}$ & $\begin{array}{l}2 \\
3 \\
4 \\
5 \\
6 \\
7\end{array}$ & $\begin{array}{l}p^{3} \\
3 p^{3} q \\
6 p^{3} q^{2} \\
10 p^{2} q^{3} \\
5 p q^{4} \\
q^{5}\end{array}$ \\
\hline 6 & $\begin{array}{l}1 \\
2 \\
3 \\
4 \\
5 \\
6\end{array}$ & $\begin{array}{l}p \\
p q \\
p q^{2} \\
p q^{3} \\
p q^{4} \\
q^{5}\end{array}$ & $\begin{array}{l}0 \\
1 \\
2 \\
3 \\
4 \\
5 \\
6\end{array}$ & $\begin{array}{l}p \\
p q \\
p q^{2} \\
p q^{3} \\
p q^{4} \\
p q^{5} \\
q^{6}\end{array}$ & $\begin{array}{l}2 \\
3 \\
4 \\
5 \\
6 \\
7\end{array}$ & $\begin{array}{l}p^{2} \\
2 p^{2} q \\
3 p^{2} q^{2} \\
4 p^{2} q^{3} \\
5 p q^{4} \\
q^{5}\end{array}$ & $\begin{array}{l}1 \\
2 \\
3 \\
4 \\
5 \\
6 \\
7\end{array}$ & $\begin{array}{l}p^{2} \\
2 p^{2} q \\
3 p^{2} q^{2} \\
4 p^{2} q^{3} \\
5 p^{2} q^{4} \\
6 p q^{5} \\
q^{6}\end{array}$ & $\begin{array}{l}3 \\
4 \\
5 \\
6 \\
7 \\
8\end{array}$ & $\begin{array}{l}p^{3} \\
3 p^{3} q \\
6 p^{3} q^{2} \\
10 p^{2} q^{3} \\
5 p q^{4} \\
q^{5}\end{array}$ & $\begin{array}{l}2 \\
3 \\
4 \\
5 \\
6 \\
7 \\
8\end{array}$ & $\begin{array}{l}p^{3} \\
3 p^{3} q \\
6 p^{3} q^{2} \\
10 p^{3} q^{3} \\
15 p^{2} q^{4} \\
6 p q^{5} \\
q^{6}\end{array}$ \\
\hline 7 & $\begin{array}{l}1 \\
2 \\
3 \\
4 \\
5 \\
6 \\
7\end{array}$ & $\begin{array}{l}p \\
p q \\
p q^{2} \\
p q^{3} \\
p q^{4} \\
p q^{5} \\
q^{6}\end{array}$ & $\begin{array}{l}0 \\
1 \\
2 \\
3 \\
4 \\
5 \\
6 \\
7\end{array}$ & $\begin{array}{l}p \\
p q \\
p q^{2} \\
p q^{3} \\
p q^{4} \\
p q^{5} \\
p q^{6} \\
q^{7}\end{array}$ & $\begin{array}{l}2 \\
3 \\
4 \\
5 \\
6 \\
7 \\
8\end{array}$ & $\begin{array}{l}p^{2} \\
2 p^{2} q \\
3 p^{2} q^{2} \\
4 p^{2} q^{3} \\
5 p^{2} q^{4} \\
6 p q^{5} \\
q^{6}\end{array}$ & $\begin{array}{l}1 \\
2 \\
3 \\
4 \\
5 \\
6 \\
7 \\
8\end{array}$ & $\begin{array}{l}p^{2} \\
2 p^{2} q \\
3 p^{2} q^{2} \\
4 p^{2} q^{3} \\
5 p^{2} q^{4} \\
6 p^{2} q^{5} \\
7 p q^{6} \\
q^{7}\end{array}$ & $\begin{array}{l}3 \\
4 \\
5 \\
6 \\
7 \\
8 \\
9\end{array}$ & $\begin{array}{l}p^{3} \\
3 p^{3} q \\
6 p^{3} q^{2} \\
10 p^{3} q^{3} \\
15 p^{2} q^{4} \\
6 p q^{5} \\
q^{6}\end{array}$ & $\begin{array}{l}2 \\
3 \\
4 \\
5 \\
6 \\
7 \\
8 \\
9\end{array}$ & $\begin{array}{l}p^{3} \\
3 p^{3} q \\
6 p^{3} q^{2} \\
10 p^{3} q^{3} \\
15 p^{3} q^{4} \\
21 p^{2} q^{5} \\
7 p q^{6} \\
q^{7}\end{array}$ \\
\hline
\end{tabular}


and more alcoholic types, which are not aged under a film, the solera may be drawn on less frequently, and a lesser portion may be drawn off each time.

A brief report of a simple solera system has been published elsewhere (Baker, Amerine, and Roessler, 1951). More complete descriptions of the operation of the system in Spain are given by González Gordon (1935 and 1948) and by Cruess (1948).

Fractional-blending systems similar to the solera system are now being introduced into California for the production of sherry. Even though the general principles of operation are the same as in Spain, it may not be desir-

TABLE 2

CONTENTS OF THE LAST BARREL IN A FRACTIONAL-BLENDING SYSTEM 8 BARRELS DEEP AFTER A CERTAIN NUMBER OF DRAWINGS-OFF

WHEN THE PERIOD IS ONE YEAR

\begin{tabular}{|c|c|c|c|c|c|c|c|c|c|c|c|c|c|}
\hline \multirow{2}{*}{$\begin{array}{l}\text { Num- } \\
\text { ber of } \\
\text { draw- } \\
\text { ings }\end{array}$} & \multicolumn{13}{|c|}{ Age of wine, years } \\
\hline & 7 & 8 & 9 & 10 & 11 & 12 & 13 & 14 & 15 & 16 & 17 & 18 & 19 \\
\hline 1 & $p$ & $q$ & & & & & & & & & & & \\
\hline 2 & $p^{2}$ & $2 p q$ & $q^{2}$ & & & & & & & & & & \\
\hline 3 & $p^{3}$ & $3 p^{2} q$ & $3 p q^{2}$ & $q^{3}$ & & & & & & & & & \\
\hline 4 & $p^{4}$ & $4 p^{3} q$ & $6 p^{2} q^{2}$ & $4 p q^{3}$ & $q^{4}$ & & & & & & & & \\
\hline 5 & $p^{5}$ & $5 p^{4} q$ & $10 p^{3} q^{2}$ & $10 p^{2} q^{3}$ & $5 p q^{4}$ & $q^{5}$ & & & & & & & \\
\hline 6 & $p^{6}$ & $6 p^{5} q$ & $15 p^{4} q^{2}$ & $20 p^{3} q^{3}$ & $15 p^{2} q^{4}$ & $6 p q^{5}$ & $q^{6}$ & & & & & & \\
\hline 7 & $p^{7}$ & $7 p^{6} q$ & $21 p^{5} q^{2}$ & $35 p^{4} q^{3}$ & $35 p^{3} q^{4}$ & $21 p^{2} q^{5}$ & $7 p q^{6}$ & $q^{7}$ & & & & & \\
\hline 8 & $p^{8}$ & $8 p^{7} q$ & $28 p^{6} q^{2}$ & $56 p^{5} q^{3}$ & $70 p^{4} q^{4}$ & $56 p^{3} q^{5}$ & $28 p^{2} q^{6}$ & $8 p q^{7}$ & $q^{8}$ & & & & \\
\hline 9 & $p^{8}$ & $8 p^{8} q$ & $36 p^{7} q^{2}$ & $84 p^{6} q^{3}$ & $126 p^{5} q^{4}$ & $126 p^{4} q^{5}$ & $84 p^{3} q^{6}$ & $36 p^{2} q^{7}$ & $9 p q^{8}$ & $q^{9}$ & & & \\
\hline 10 & $p^{8}$ & $8 p^{8} q$ & $36 p^{8} q^{2}$ & $120 p^{7} q^{3}$ & $210 p^{6} q^{4}$ & $252 p^{5} q^{5}$ & $210 p^{4} q^{6}$ & $120 p^{3} q^{7}$ & $45 p^{2} q^{8}$ & $10 p q^{9}$ & $q^{10}$ & & \\
\hline 11 & $p^{8}$ & $8 p^{8} q$ & $36 p^{8} q^{2}$ & $120 p^{8} q^{3}$ & $330 p^{7} q^{4}$ & $462 p^{6} q^{5}$ & $462 p^{5} q^{6}$ & $330 p^{4} q^{7}$ & $165 p^{3} q^{8}$ & $55 p^{2} q^{9}$ & $11 p q^{10}$ & $q^{11}$ & \\
\hline 12 & $p^{8}$ & $8 p^{8} q$ & $36 p^{8} q^{2}$ & $120 p^{8} q^{3}$ & $330 p^{8} q^{4}$ & $792 p^{7} q^{5}$ & $924 p^{6} q^{6}$ & $792 p^{5} q^{7}$ & $495 p^{4} q^{8}$ & $220 p^{3} q^{9}$ & $66 p^{2} q^{10}$ & $12 p q^{11}$ & $q^{12}$ \\
\hline
\end{tabular}

able to apply the word solera to the processes used in California since various modifications of the Spanish system have been introduced, and the word is already so closely associated with the Spanish sherry industry.

\section{THEORETICAL DEVELOPMENT}

In order to explain the method of calculation used in this study, let us consider a system of 3 stages or barrels. Let $p$ equal the proportion drawn off at the end of each period and $q$ the proportion not drawn off. At the beginning, the third or bottom barrel in the system contains wine 2 years old, and the second barrel contains wine 1 year old, and the first or top barrel, wine 0 years old. The details of the operation of such a system for seven periods of one year are shown in Table 1 . The complex mixture of wine from 3 to 9 years of age in the bottom barrel at the end of seven periods and before drawing off is indicated at the bottom of the last column.

As a further illustration of the method, let us consider an 8-stage or 8-barrel system. The expression for the last barrel after 1 to 12 drawings-off and replacements is shown in Table 2. Up to the number of drawings corresponding with the number of barrels in the system-in this case 8 - the expression is derived from the binomial expansion of $(p+q)^{\mathrm{n}}$, where $n$ equals the number of drawings. After that the $p^{\mathrm{n}}$ term-in our illustration $p^{8}$-remains unchanged. The terms for later years are obtained as follows: the 
coefficient 36 of the term $p^{7} q^{2}$ is the sum of the two coefficients $(8+28)$ above it and to the left in the line above; and so on for the other coefficients to the right and below. With a constant percentage withdrawal made once a year, the coefficient remains constant for any age of wine after the number of drawings-off corresponds with the age of the wine. Thus, in the column for 9 -year-old wine, the coefficient 36 becomes constant after 9 drawings-off.

From such a tabulation as Table 2, the average age in the last barrel after any drawing-off can be calculated by substituting a given proportion of withdrawal for the term $p$ and multiplying by the age of the wine in each column. Thus if $p=0.25$, then after the first drawing-off (when the oldest barrel, 8 years old, has been filled with 25 per cent of the wine 7 years old), the average age of the wine in the oldest barrel will be $(7$ years $\times 0.25)+(8$ years $\times 0.75)$, or 7.75 years. After three years of operation the average age of the wine in the last barrel will be $\left(7\right.$ years $\left.\times 0.25^{3}\right)+\left(8\right.$ years $\left.\times 3 \times 0.25^{2} \times 0.75\right)+(9$ years $\left.\times 3 \times 0.25 \times 0.75^{2}\right)+\left(10\right.$ years $\left.\times 0.75^{3}\right)$, or 9.25 years.

This illustrates the method used in calculating average age with drawingsoff once a year. An adaptation is necessary when wine is drawn off at more frequent intervals; this will be explained when the average age with more frequent drawings-off is taken up.

\section{AVERAGE AGE}

The average age of the contents of the last barrel depends on the fractionalblending system used and the length of time the system has been in operation.

The various fractional-blending systems applicable to wines differ in (1) frequency of drawing off, (2) the,proportion withdrawn each time, (3) the number of stages (barrels) used, and (4) the age of the contents of each barrel at the start. All of these factors affect the average age of the last barrel's contents after any given period of operation.

The average age increases rather rapidly in the first years of operation, but finally reaches a maximum and is constant thereafter. The maximum average age that is finally attained and the period of operation required to attain a constant age depend (mostly) on the first three factors listed in the preceding paragraph.

In this study, calculations were made of the average age of the last barrel's contents for three frequencies of drawing off (annual, semiannual, and quarterly), for three proportions of withdrawals $(10,25$, and 50 per cent), for 4 to 8 stages (barrels), and for fifty years of operation.

In actual practice, the fill-up wine may vary somewhat in age. In the calculations that follow, an annual system was filled with wine of 0 age, a semiannual one with 0 and 6 months' wine, and a quarterly one with $0,3,6$, and 9 months' wine. The assumptions made as to the age of the wine in the other barrels at the start of the system will be explained for each frequency of drawing off.

With Annual Drawing-off. In the calculations with annual drawing-off, it is assumed that at the start each successive barrel contains wine a year older than the next younger barrel. Thus, at the start of a 4-barrel system, the first barrel would contain wine of 0 age; the second barrel, wine 1 year old; the third barrel, wine 2 years old; and the fourth barrel, wine 3 years old. 
TABLE 3

AVERAGE AGE IN YEARS OF THE CONTENTS OF THE LAST BARREL OF CERTAIN SYSTEMS AFTER THE INDICATED NUMBER OF DRAWINGS-OFF AND REPLACEMENTS AT ONE-YEAR INTERVALS

\begin{tabular}{|c|c|c|c|c|c|c|c|c|c|c|}
\hline \multirow{2}{*}{$\begin{array}{l}\text { Number of } \\
\text { drawings } \\
\text { (and year } \\
\text { of operation) }\end{array}$} & \multicolumn{2}{|c|}{ 4-barrel system } & \multicolumn{2}{|c|}{ 5-barrel system } & \multicolumn{2}{|c|}{ 6-barrel system } & \multicolumn{2}{|c|}{ 7-barrel system } & \multicolumn{2}{|c|}{ 8-barrel system } \\
\hline & $p=0.25$ & $p=0.10$ & $p=0.25$ & $p=0.10$ & $p=0.25$ & $p=0.10$ & $p=0.25$ & $p=0.10$ & $p=0.25$ & $p=0.10$ \\
\hline 1. & 3.75 & 3.90 & 4.75 & 4.90 & 5.75 & 5.90 & 6.75 & 6.90 & 7.75 & 7.90 \\
\hline 2. & 4.50 & 4.80 & 5.50 & 5.80 & 6.50 & 6.80 & 7.50 & 7.80 & 8.50 & 8.80 \\
\hline 3. & 5.25 & 5.70 & 6.25 & 6.70 & 7.25 & 7.70 & 8.25 & 8.70 & 9.25 & 9.70 \\
\hline 4. & 6.00 & 6.60 & 7.00 & 7.60 & 8.00 & 8.60 & 9.00 & 9.60 & 10.00 & 10.60 \\
\hline 5 . & 6.75 & 7.50 & 7.75 & 8.50 & 8.75 & 9.50 & 9.75 & 10.50 & 10.75 & 11.50 \\
\hline 6. & 7.49 & 8.40 & 8.50 & 9.40 & 9.50 & 10.40 & 10.50 & 11.40 & 11.50 & 12.40 \\
\hline 7. & 8.21 & 9.30 & 9.25 & 10.30 & 10.25 & 11.30 & 11.25 & 12.30 & 12.25 & 13.30 \\
\hline 8. . & 8.90 & 10.20 & 9.99 & 11.20 & 11.00 & 12.20 & 12.00 & 13.20 & 13.00 & 14.20 \\
\hline 9. & 9.57 & 11.09 & 10.72 & 12.10 & 11.75 & 13.10 & 12.75 & 14.10 & 13.75 & 15.10 \\
\hline 10. & 10.20 & 11.98 & 11.43 & 13.00 & 12.49 & 14.00 & 13.50 & 15.00 & 14.50 & 16.00 \\
\hline 11. & 10.78 & 12.87 & 12.12 & 13.90 & 13.22 & 14.90 & 14.25 & 15.90 & 15.25 & 16.90 \\
\hline 12. & 11.31 & 13.76 & 12.78 & 14.80 & 13.95 & 15.80 & 14.99 & 16.80 & 16.00 & 17.80 \\
\hline 13. & 11.80 & 14.63 & 13.42 & 15.69 & 14.66 & 16.70 & 15.73 & 17.70 & 16.75 & 18.70 \\
\hline$\ldots \ldots$ & 12.24 & 15.50 & 14.01 & 16.59 & 15.35 & 17.60 & 16.46 & 18.60 & 17.49 & 19.60 \\
\hline $15 \ldots \ldots \ldots$ & 12.63 & 16.36 & 14.57 & 17.48 & 16.01 & 18.50 & 17.18 & 19.50 & 18.24 & 20.50 \\
\hline$\ldots \ldots$ & 12.97 & 17.21 & 15.08 & 18.37 & 16.65 & 19.40 & 17.89 & 20.40 & 18.97 & 21.40 \\
\hline$\ldots \ldots$ & 13.28 & 18.05 & 15.56 & 19.25 & 17.26 & 20.29 & 18.58 & 21.30 & 19.70 & 22.30 \\
\hline 18. & 13.54 & 18.88 & 15.99 & 20.13 & 17.83 & 21.19 & 19.25 & 22.20 & 20.42 & 23.20 \\
\hline 19. & 13.77 & 19.69 & 16.38 & 21.01 & 18.34 & 22.08 & 19.90 & 23.10 & 21.13 & 24.10 \\
\hline 20. & 13.97 & 20.48 & 16.72 & 21.87 & 18.87 & 22.97 & 20.52 & 24.00 & 21.82 & 25.00 \\
\hline 21. & 14.14 & 21.27 & 17.04 & 22.73 & 19.34 & 23.86 & 21.10 & 24.89 & 22.49 & 25.90 \\
\hline 22. & 14.28 & 22.03 & 17.31 & 23.59 & 19.76 & 24.75 & 21.66 & 25.79 & 23.29 & 26.80 \\
\hline 23. & 14.40 & 22.77 & 17.55 & 24.43 & 20.15 & 25.64 & 22.19 & 26.69 & 23.88 & 27.70 \\
\hline 24. & 14.51 & 23.50 & 17.77 & 25.27 & 20.50 & 26.51 & 22.68 & 27.57 & 24.46 & 28.60 \\
\hline 25 . & 14.59 & 24.21 & 17.95 & 26.09 & 20.82 & 27.39 & 23.13 & 28.46 & 25.01 & 29.49 \\
\hline 26. & 14.66 & 24.89 & 18.11 & 26.90 & 21.10 & 28.26 & 23.55 & 29.35 & 25.54 & 30.39 \\
\hline 27. & 14.72 & 25.56 & 18.25 & 27.70 & 21.35 & 29.12 & 23.94 & 30.24 & 26.05 & 31.29 \\
\hline 28 . & 14.77 & 26.21 & 18.37 & 28.49 & 21.58 & 29.98 & 24.29 & 31.13 & 26.52 & 32.18 \\
\hline 29 . & 14.82 & 26.83 & 18.47 & 29.26 & 21.77 & 30.83 & 24.61 & 32.02 & 26.96 & 33.08 \\
\hline 30. & 14.85 & 27.44 & 18.56 & 30.02 & 21.95 & 31.67 & 24.90 & 32.90 & 27.38 & 33.97 \\
\hline $31 \ldots$ & 14.88 & 28.02 & 18.63 & 30.76 & 22.10 & 32.51 & 25.17 & 33.78 & 27.76 & 34.86 \\
\hline 32. & 14.90 & 28.58 & 18.69 & 31.48 & 22.23 & 33.33 & 25.40 & 34.65 & 28.11 & 35.76 \\
\hline 33. & 14.92 & 29.12 & 18.74 & 32.19 & 22.35 & 34.15 & 25.61 & 35.52 & 28.43 & 36.64 \\
\hline 34. & 14.94 & 29.64 & 18.79 & 32.89 & 22.45 & 34.95 & 25.79 & 36.38 & 28.73 & 37.53 \\
\hline 35. & 14.95 & 30.14 & 18.82 & 33.56 & 22.53 & 35.75 & 25.96 & 37.24 & 28.99 & 38.42 \\
\hline 36. & 14.96 & 30.62 & 18.86 & 34.22 & 22.61 & 36.53 & 26.10 & 38.09 & 29.23 & 39.30 \\
\hline 37. & 14.97 & 31.07 & 18.88 & 34.85 & 22.67 & 37.30 & 26.23 & 38.93 & 29.45 & 40.18 \\
\hline 38. & 14.97 & 31.51 & 18.90 & 35.46 & 22.72 & 38.05 & 26.34 & 39.77 & 29.64 & 41.05 \\
\hline 39. & 14.98 & 31.93 & 18.92 & 36.05 & 22.77 & 38.79 & 26.43 & 40.60 & 29.82 & 41.93 \\
\hline 40. & 14.99 & 32.33 & 18.93 & 36.62 & 22.80 & 39.52 & 26.52 & 41.42 & 29.97 & 42.79 \\
\hline 41. & 14.99 & 32.71 & 18.95 & 37.18 & 22.84 & 40.23 & 26.59 & 42.23 & 30.11 & 43.77 \\
\hline 42. & 14.99 & 33.07 & 18.96 & 37.72 & 22.86 & 40.92 & 26.65 & 43.03 & 30.23 & 44.62 \\
\hline 43. & 14.99 & 33.42 & 18.96 & 38.25 & 22.89 & 41.60 & 26.70 & 43.82 & 30.33 & 45.46 \\
\hline 44. & 14.99 & 33.75 & 18.97 & 38.76 & 22.91 & 42.27 & 26.75 & 44.60 & 30.43 & 46.30 \\
\hline 45. & 14.99 & 34.06 & 18.98 & 39.25 & 22.92 & 42.92 & 26.79 & 45.36 & 30.51 & 47.13 \\
\hline 46. & 15.00 & 34.35 & 18.98 & 39.72 & 22.94 & 43.55 & 26.82 & 46.12 & 30.58 & 47.95 \\
\hline 47. & 15.00 & 34.64 & 18.99 & 40.18 & 22.95 & 44.17 & 26.85 & 46.86 & 30.64 & 48.77 \\
\hline 48. & 15.00 & 34.90 & 18.99 & 40.62 & 22.96 & 44.77 & 26.88 & 47.59 & 30.69 & 49.58 \\
\hline $49 \ldots \ldots \ldots$ & 15.00 & 35.13 & 18.99 & 41.04 & 22.96 & 45.35 & 26.90 & 48.31 & 30.74 & 50.38 \\
\hline $50 \ldots \ldots \ldots$ & 15.00 & 35.39 & 18.99 & 41.45 & 22.97 & $45: 92$ & 26.91 & 49.01 & 30.78 & 51.17 \\
\hline
\end{tabular}


The results for yearly drawings-off are presented in Tables 3 and 4 and graphically in Figures 1, 2, and 3. The tables are included because of needed accuracy and to indicate more clearly the structures of the systems. The graphs are necessary to give one a quick over-all grasp of the effect of changing various characteristics of the systems.

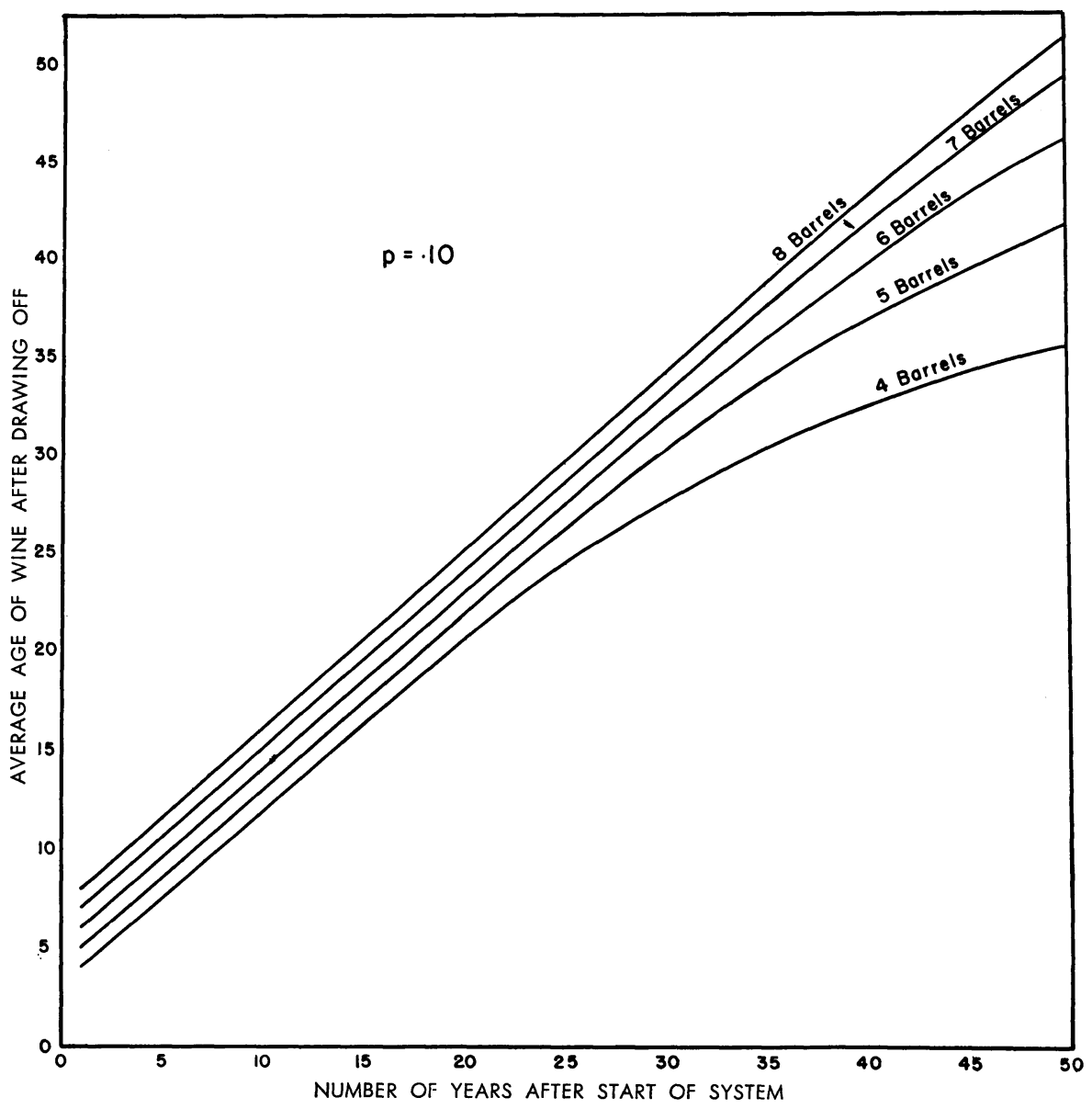

Fig. 1. Average age of the wine in the oldest container of 4, 5, 6, 7, and 8-barrel systems when 10 per cent is removed once a year.

Figure 1 for a 10 per cent drawing-off each year shows that the average age of the contents of the oldest barrel in the 4-barrel system is just beginning to approach a constant value of 35 years after 40 years of operation, while the oldest barrel of the 8-barrel system has an average age of over 51 years that is still rapidly increasing.

Figure 2 indicates that in a system of 4 barrels when 25 per cent is removed once a year from the oldest barrel, the average age of its contents increases to a constant value of 15 years after about 39 years of operation, though the rate of increase in average age is very slow after only about 25 years. The 5 -barrel 


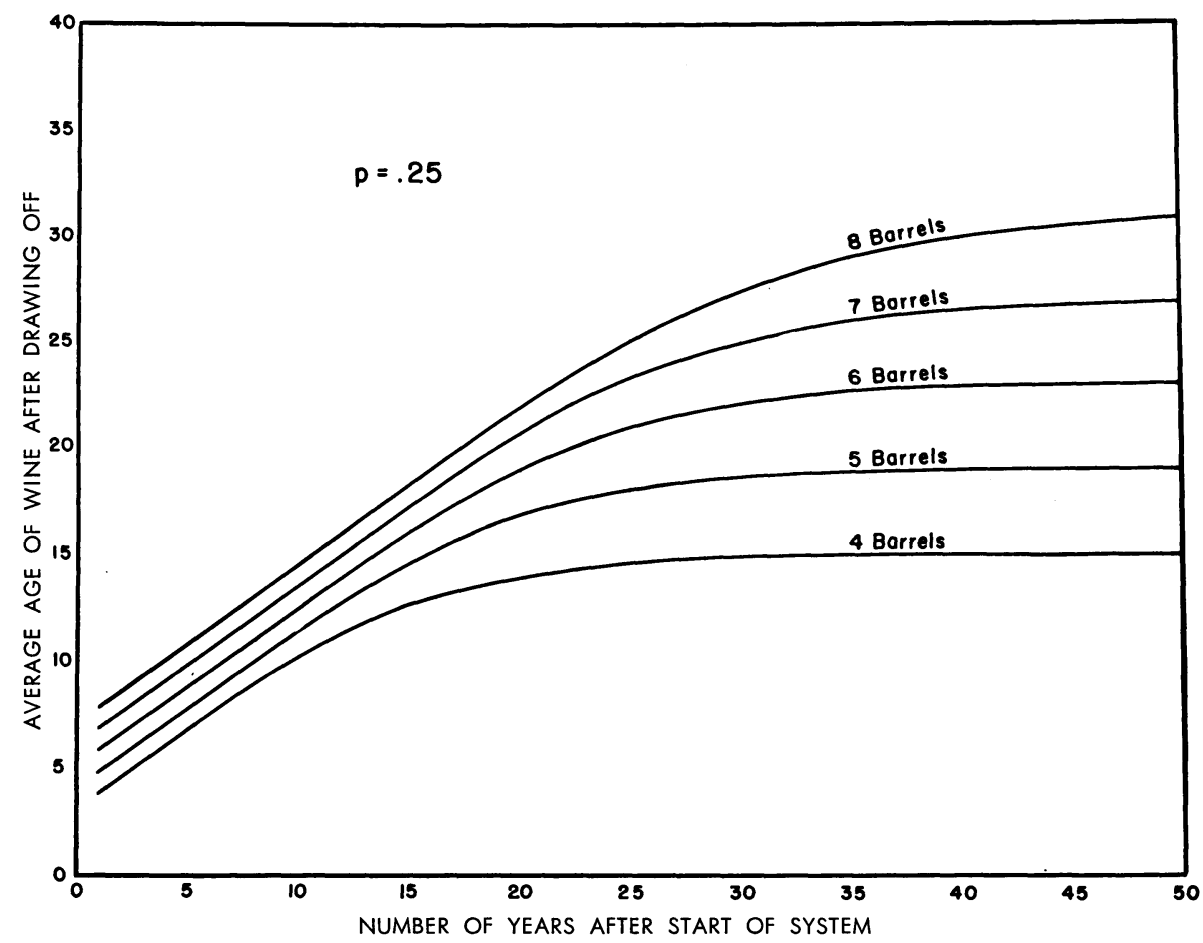

Fig. 2. Average age of the wine in the oldest container of 4, 5, 6, 7, and 8-barrel systems when 25 per cent is removed once a year.

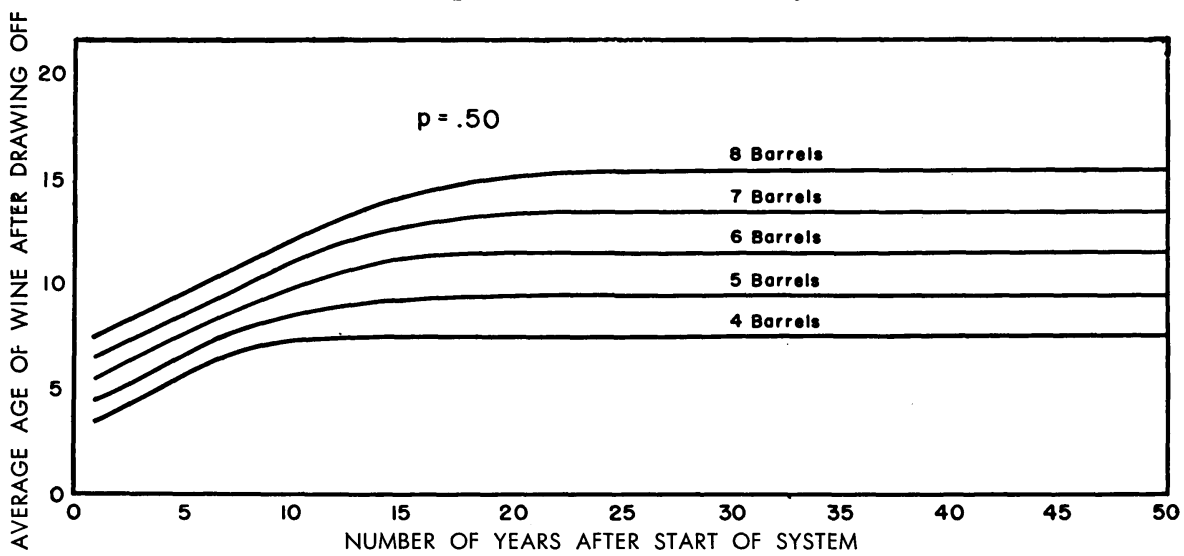

Fig. 3. Average age of the wine in the oldest container of 4, 5, 6, 7, and 8-barrel systems when 50 per cent is removed once a year.

system approaches a constant age of 19 years after a slightly longer period of time, the 6-barrel system gradually approaches a 23-year average, and the 7-barrel system 27 years. The average age of the contents of the oldest barrel of an 8-barrel system is still increasing slowly after 50 years' operation and is 31 years. 
Under commercial conditions a once-a-year drawing-off of 50 per cent might be more practicable than the four-times-a-year 10 and 25 per cent systems to be discussed later. Table 4 shows that under the once-a-year, 50 per cent system the average age quickly becomes stable after relatively few years. There is little change after 14 years for a 4-barrel system, 17 years for

TABLE 4

AVERAGE AGE IN YEARS OF THE CONTENTS OF THE LAST BARREL OF CERTAIN SYSTEMS AFTER THE INDICATED NUMBER OF DRAWINGS-OFF AND REPLACEMENTS AT YEARLY INTERVALS

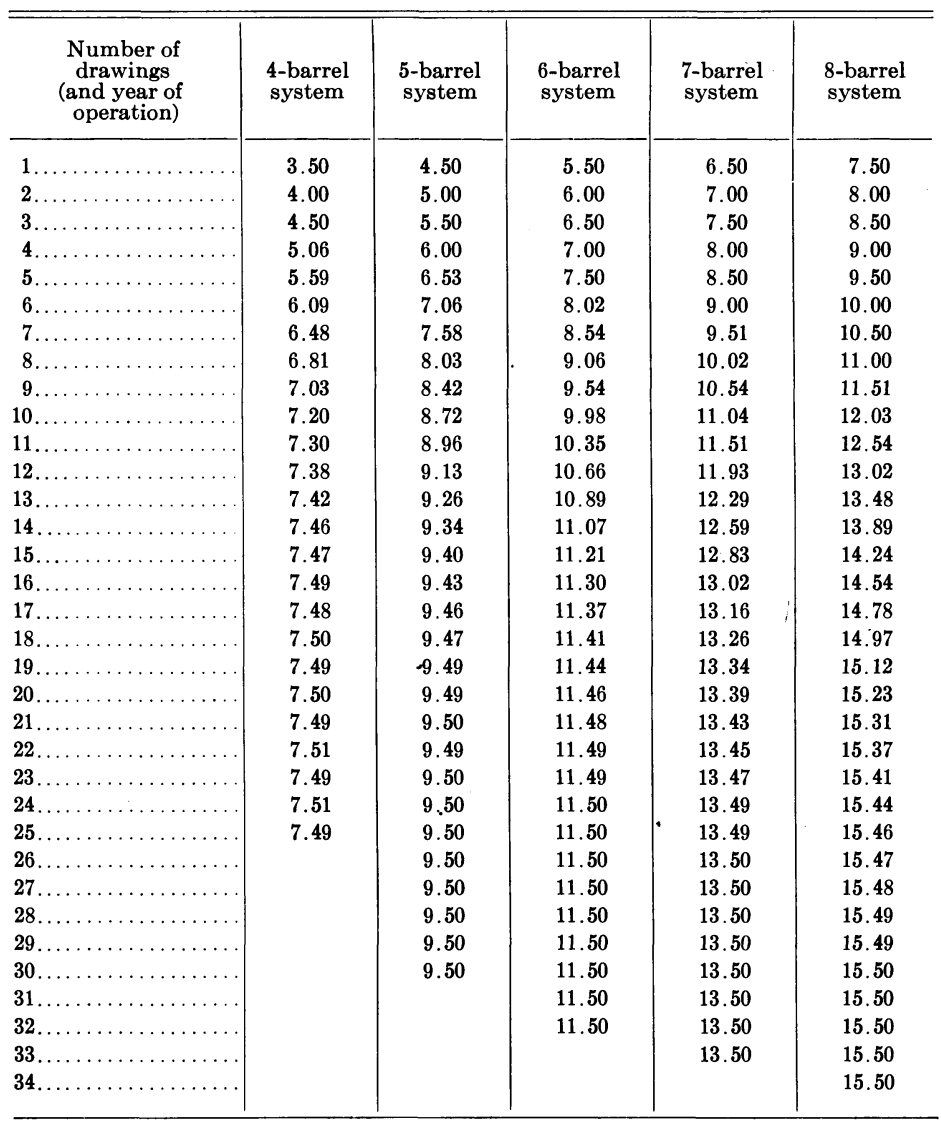

a 5-barrel system, 20 years for a 6 -barrel system, 23 years for a 7 -barrel system, and 25 years for an 8-barrel system. The oldest averages attained are $7.5,9.5,11.5,13.5$, and 15.5 respectively. These can be compared with 15.0, $19.0,23.0,27.0$, and 31.0 of Table 3 to indicate the effectiveness of the smaller proportion of drawing-off in increasing the maximum average age reached. Figure 3 summarizes the data of table 4 and shows graphically the more rapid leveling off and the lower average age reached when 50 per cent is withdrawn once a year as compared with 25 per cent (figure 2 ). 
With Semiannual Drawing-off. It is obvious then that for a given number of years of operation, one may increase the average age in the last barrel by $(a)$ increasing the number of barrels in the system or $(b)$ decreasing the per cent drawn off each year.

In the foregoing section we have assumed that the age of the wine in the successive barrels differs by one year. This is not true, of course, when wine is drawn off each 6 months. In this case, the age of the fill-up wine for the youngest container will vary from very young wine to wine 6 months to a year older, since the vintage occurs only once a year. The method of calculating the average age of the wine in such a case is indicated in Table 5 for a 3 -barrel system for 4 years of operation. Table 6 summarizes the formulas used in calculating the average age in the oldest barrel of an 8-barrel system, after 1 to 12 drawings-off at 6 -month intervals. It should be noted that the period interval is $1 / 2$ year. At the beginning of this system the age (in halfyear periods) is as follows:

\begin{tabular}{l|c|c|c|c|c}
\hline \hline \multirow{2}{*}{ Barrel No. } & \multicolumn{4}{|c}{ Age in number of half-year periods } \\
\cline { 2 - 6 } & $\begin{array}{c}4 \\
\text { barrels }\end{array}$ & $\begin{array}{c}5 \\
\text { barrels }\end{array}$ & $\begin{array}{c}6 \\
\text { barrels }\end{array}$ & $\begin{array}{c}7 \\
\text { barrels }\end{array}$ & $\begin{array}{c}8 \\
\text { barrels }\end{array}$ \\
\hline $1 \ldots \ldots \ldots \ldots \ldots \ldots \ldots \ldots$ & 0 & 0 & 0 & 0 & 0 \\
$2 \ldots \ldots \ldots \ldots \ldots \ldots \ldots \ldots \ldots$ & 0 & 2 & 0 & 2 & 0 \\
$3 \ldots \ldots \ldots \ldots \ldots \ldots \ldots \ldots \ldots$ & 2 & 2 & 2 & 2 & 2 \\
$4 \ldots \ldots \ldots \ldots \ldots \ldots \ldots \ldots \ldots$ & 2 & 4 & 2 & 4 & 2 \\
$5 \ldots \ldots \ldots \ldots \ldots \ldots \ldots \ldots \ldots$ & & 4 & 4 & 4 & 4 \\
$6 \ldots \ldots \ldots \ldots \ldots \ldots \ldots \ldots \ldots$ & & & 4 & 6 & 4 \\
$7 \ldots \ldots \ldots \ldots \ldots \ldots \ldots \ldots$ & & & & 6 & 6 \\
$8 \ldots \ldots \ldots \ldots \ldots \ldots \ldots \ldots$ & & & & & 6 \\
\hline
\end{tabular}

Hereafter this is called fractional-blending system type "A."

Table 7 gives the average age, in half years, of the contents of the last barrel where the drawings-off are made every 6 months, the proportion withdrawn each time is 25 and 10 per cent, and the contents at the start.are as indicated in the previous paragraph. These data are summarized in Figures 4 and 5, except that the actual age is shown and not the age in half-year periods.

Figure 4 shows that for a 25 per cent drawing-off the average age of the contents of the oldest barrel approaches an average age of $91 / 2$ years after 15 years, the 6 -barrel system $11 \frac{1}{2}$ years after 18 years, the 7 -barrel system $131 / 2$ years after 20 years, and the 8-barrel system 151/2 years after 23 years of storage.

For a 10 per cent drawing-off (figure 5) the average age is increasing for all systems after 25 years, though the rate of increase in age of the 4-barrel systems is, of course, slower. 


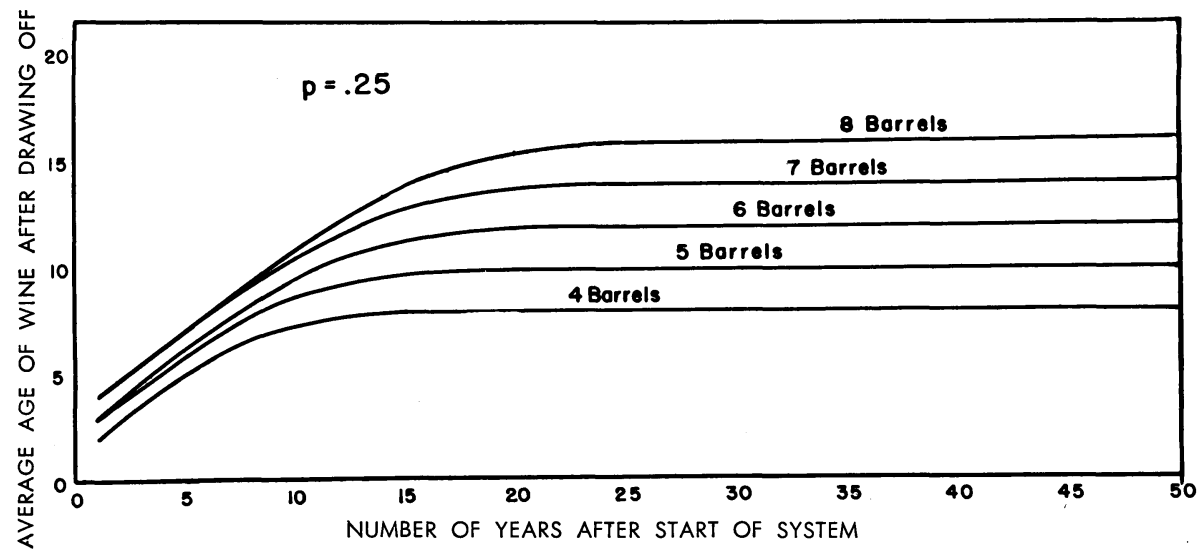

Fig. 4. Average age of the wine in the oldest container of 4, 5, 6, 7, and 8-barrel systems when 25 per cent of the wine is removed each six months and the original system is type "A."

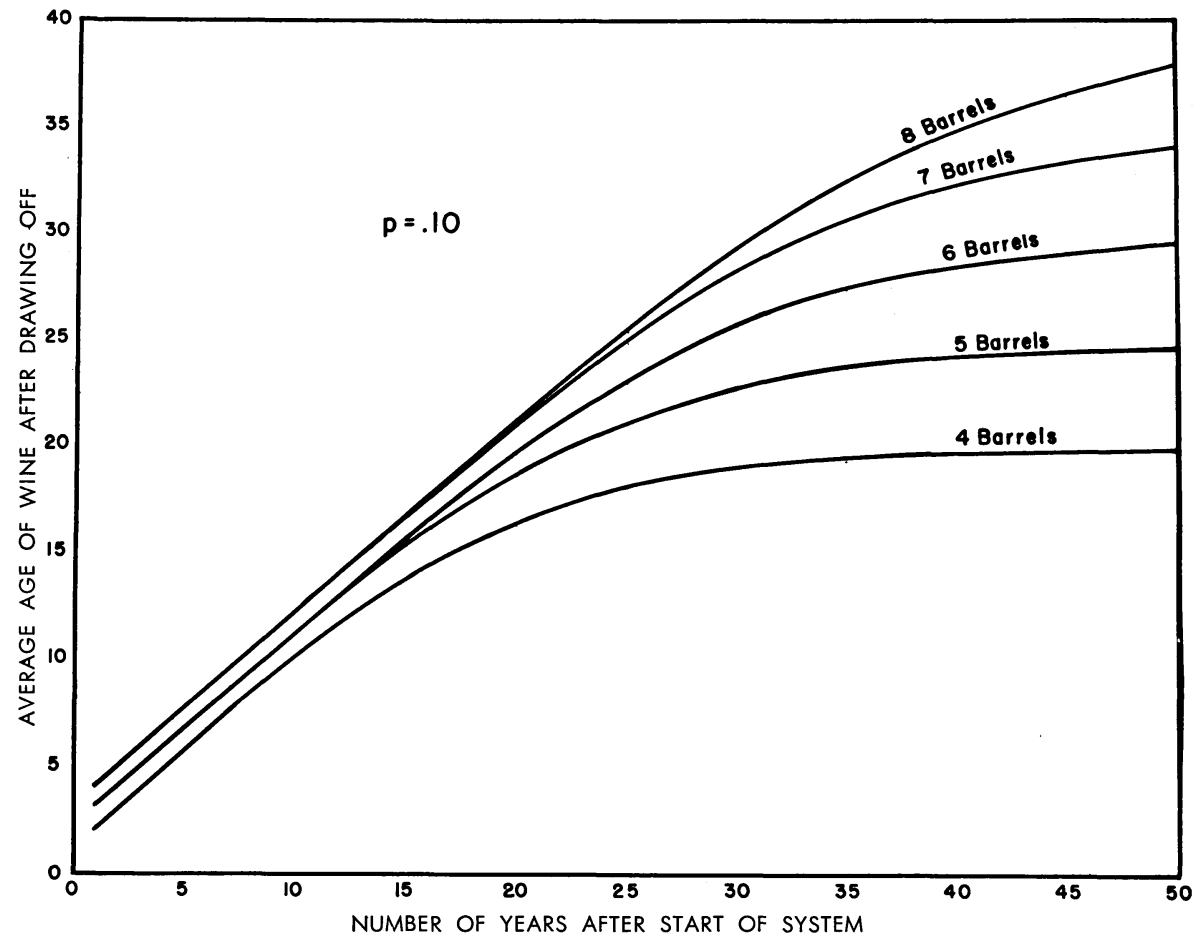

Fig. 5. Average age of the wine in the oldest container of 4, 5, 6, 7, and 8-barrel systems when 10 per cent of the wine is removed each six months and the original system is type "A." 


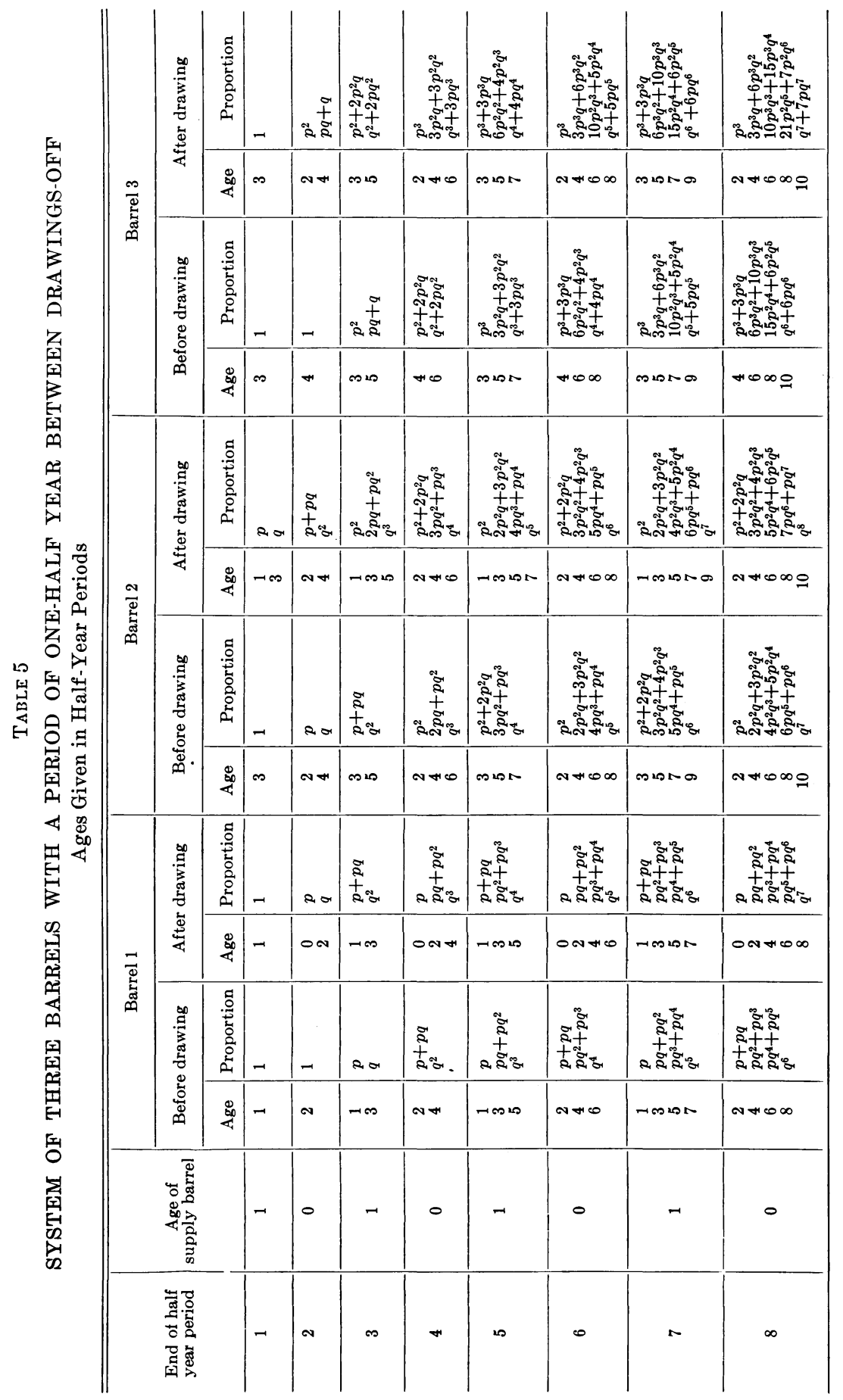


TABLE 6

CONTENTS OF THE LAST BARREL OF A SYSTEM OF EIGHT BARRELS AFTER A CERTAIN NUMBER OF DRAWINGS WHEN THE PERIOD BETWEEN DRAWINGS-OFF IS ONE-HALF YEAR

\begin{tabular}{|c|c|c|}
\hline $\begin{array}{l}\text { Number of } \\
\text { drawings }\end{array}$ & Age & Proportions \\
\hline 1 & 7 & 1 \\
\hline 2 & $\begin{array}{l}6 \\
8\end{array}$ & $\begin{array}{l}p^{2} \\
p q+q\end{array}$ \\
\hline 3 & $\begin{array}{l}7 \\
9\end{array}$ & $\begin{array}{l}p^{2}+2 p^{2} q \\
2 p q^{2}+q^{2}\end{array}$ \\
\hline 4 & $\begin{array}{r}6 \\
8 \\
10\end{array}$ & $\begin{array}{l}p^{4} \\
p^{3} q+3 p^{2} q+3 p^{2} q^{2} \\
3 p q^{3}+q^{3}\end{array}$ \\
\hline 5 & $\begin{array}{r}7 \\
9 \\
11\end{array}$ & $\begin{array}{l}p^{4}+4 p^{4} q \\
4 p^{3} q^{2}+6 p^{2} q^{2}+4 p^{2} q^{3} \\
4 p q^{4}+q^{4}\end{array}$ \\
\hline 6 & $\begin{array}{r}6 \\
8 \\
10 \\
12\end{array}$ & $\begin{array}{l}p^{6} \\
p^{5} q+5 p^{4} q+10 p^{4} q^{2} \\
10 p^{3} q^{3}+10 p^{2} q^{3}+5 p^{2} q^{4} \\
5 p q^{5}+q^{5}\end{array}$ \\
\hline 7 & $\begin{array}{r}7 \\
9 \\
11 \\
13\end{array}$ & $\begin{array}{l}p^{6}+6 p^{6} q \\
6 p^{5} q^{2}+15 p^{4} q^{2}+20 p^{4} q^{3} \\
20 p^{3} q^{4}+15 p^{2} q^{4}+6 p^{2} q^{5} \\
6 p q^{6}+q^{6}\end{array}$ \\
\hline 8 & $\begin{array}{r}8 \\
10 \\
12 \\
14\end{array}$ & $\begin{array}{l}p^{6}+6 p^{6} q+21 p^{6} q^{2} \\
21 p^{5} q^{3}+35 p^{4} q^{3}+35 p^{4} q^{4} \\
35 p^{3} q^{5}+21 p^{2} q^{5}+7 p^{2} q^{6} \\
7 p q^{7}+q^{7}\end{array}$ \\
\hline 9 & $\begin{array}{r}7 \\
9 \\
11 \\
13 \\
15\end{array}$ & $\begin{array}{l}p^{8} \\
p^{7}+7 p^{6} q+21 p^{6} q^{2}+56 p^{6} q^{3} \\
56 p^{5} q^{4}+70 p^{4} q^{4}+56 p^{4} q^{5} \\
56 p^{3} q^{6}+28 p^{2} q^{6}+8 p^{2} q^{7} \\
8 p q^{8}+q^{8}\end{array}$ \\
\hline 10 & $\begin{array}{r}8 \\
10 \\
12 \\
14 \\
16\end{array}$ & $\begin{array}{l}p^{8}+8 p^{8} q \\
8 p^{7} q^{2}+28 p^{6} q^{2}+56 p^{6} q^{3}+126 p^{6} q^{4} \\
126 p^{5} q^{5}+126 p^{4} q^{5}+84 p^{4} q^{6} \\
84 p^{3} q^{7}+36 p^{2} q^{7}+9 p^{2} q^{8} \\
9 p q^{9}+q^{9}\end{array}$ \\
\hline 11 & $\begin{array}{r}7 \\
9 \\
11 \\
13 \\
15 \\
17\end{array}$ & $\begin{array}{l}p^{8} \\
8 p^{8} q+36 p^{8} q^{2} \\
36 p^{7} q^{3}+84 p^{6} q^{3}+126 p^{6} q^{4}+252 p^{6} q^{5} \\
252 p^{5} q^{6}+210 p^{4} q^{6}+120 p^{4} q^{7} \\
120 p^{3} q^{8}+45 p^{2} q^{8}+10 p^{2} q^{9} \\
10 p q^{10}+q^{10}\end{array}$ \\
\hline 12 & $\begin{array}{r}8 \\
10 \\
12 \\
14 \\
16 \\
18\end{array}$ & $\begin{array}{l}p^{8}+8 p^{8} q \\
36 p^{8} q^{2}+120 p^{8} q^{3} \\
120 p^{7} q^{4}+210 p^{6} q^{4}+252 p^{6} q^{5}+462 p^{6} q^{8} \\
462 p^{5} q^{7}+330 p^{4} q^{7}+165 p^{4} q^{8} \\
165 p^{3} q^{9}+55 p^{2} q^{9}+11 p^{2} q^{10} \\
11 p q^{11}+q^{11}\end{array}$ \\
\hline
\end{tabular}




\section{TABLE 7}

AVERAGE AGE IN HALF YEARS OF THE CONTENTS OF THE LAST

BARREL OF CERTAIN SYSTEMS AFTER THE INDICATED NUMBER OF DRAWINGS-OFF AND REPLACEMENTS

AT HALF-YEAR INTERVALS. (Type "A")

\begin{tabular}{|c|c|c|c|c|c|c|c|c|c|c|c|}
\hline \multirow{2}{*}{$\begin{array}{l}\text { Years } \\
\text { of } \\
\text { oper- } \\
\text { ation }\end{array}$} & \multirow{2}{*}{$\begin{array}{c}\text { Number } \\
\text { of } \\
\text { draw- } \\
\text { ings }\end{array}$} & \multicolumn{2}{|c|}{ 4-barrel system } & \multicolumn{2}{|c|}{ 5-barrel system } & \multicolumn{2}{|c|}{ 6-barrel system } & \multicolumn{2}{|c|}{ 7-barrel system } & \multicolumn{2}{|c|}{ 8-barrel system } \\
\hline & & $p=0.25$ & $p=0.10$ & $p=0.25$ & $p=0.10$ & $p=0.25$ & $p=0.10$ & $p=0.25$ & $p=0.10$ & $p=0.25$ & $p=0.10$ \\
\hline \multirow[t]{2}{*}{1} & 1 & 3.00 & 3.00 & 5.00 & 5.00 & 5.00 & 5.00 & 7.00 & 7.00 & 7.00 & 7.00 \\
\hline & 2 & 3.88 & 3.98 & 5.88 & 5.98 & 5.88 & 5.98 & 7.88 & 7.98 & 7.88 & 7.98 \\
\hline \multirow[t]{2}{*}{2} & 3 & 4.69 & 4.94 & 6.69 & 6.94 & 6.69 & 6.94 & 8.69 & 8.94 & 8.69 & 8.94 \\
\hline & 4 & 5.48 & 5.90 & 7.47 & 7.90 & 7.47 & 7.90 & 9.47 & 9.90 & 9.47 & 9.90 \\
\hline \multirow[t]{2}{*}{3} & 5 & 6.26 & 6.84 & 8.23 & 8.84 & 8.97 & 8.84 & 10.23 & 10.84 & 10.23 & 10.84 \\
\hline & 6 & 7.04 & 7.77 & 8.99 & 9.77 & 9.54 & 9.77 & 10.99 & 11.77 & 10.99 & 11.76 \\
\hline \multirow[t]{2}{*}{4} & 7 & 7.81 & 8.70 & 9.74 & 10.70 & 10.16 & 10.70 & 11.75 & 12.70 & 11.75 & 12.68 \\
\hline & 8 & 8.56 & 9.62 & 10.48 & 11.62 & 10.81 & 11.62 & 12.50 & 13.62 & 12.50 & 13.60 \\
\hline \multirow[t]{2}{*}{5} & 9 & 9.29 & 10.54 & 11.21 & 12.53 & 11.49 & 12.53 & 13.25 & 14.53 & 13.25 & 14.51 \\
\hline & 10 & 9.98 & 11.45 & 11.91 & 13.44 & 12.19 & 13.45 & 14.00 & 15.45 & 14.00 & 15.42 \\
\hline \multirow[t]{2}{*}{6} & 11 & 10.64 & 12.36 & 12.60 & 14.35 & 12.90 & 14.36 & 14.74 & 16.36 & 14.75 & 16.33 \\
\hline & 12 & 11.24 & 13.26 & 13.26 & 15.26 & 13.62 & 15.27 & 15.49 & 17.27 & 15.50 & 17.24 \\
\hline \multirow[t]{2}{*}{7} & 13 & 11.79 & 14.15 & 13.89 & 16.16 & 14.34 & 16.17 & 16.23 & 18.17 & 16.26 & 18.14 \\
\hline & 14 & 12.29 & 15.04 & 14.48 & 17.06 & 15.05 & 17.08 & 16.96 & 19.08 & 17.01 & 19.05 \\
\hline \multirow[t]{2}{*}{8} & 15 & 12.74 & 15.92 & 15.03 & 17.96 & 15.74 & 17.98 & 17.67 & 19.98 & 17.77 & 19.94 \\
\hline & 16 & 13.14 & 16.79 & 15.55 & 18.85 & 16.42 & 18.89 & 18.38 & 20.89 & 18.52 & 20.84 \\
\hline \multirow[t]{2}{*}{9} & 17 & 13.49 & 17.65 & 16.02 & 19.73 & 17.07 & 19.79 & 19.07 & 21.79 & 19.27 & 21.74 \\
\hline & 18 & 13.80 & 18.50 & 16.45 & 20.61 & 17.69 & 20.69 & 19.73 & 22.69 & 20.01 & 22.64 \\
\hline \multirow[t]{2}{*}{10} & 19 & 14.07 & 19.33 & 16.84 & 21.49 & 18.28 & 21.59 & 20.37 & 23.59 & 20.74 & 23.54 \\
\hline & 20 & 14.30 & 20.15 & 17.19 & 22.36 & 18.83 & 22.48 & 20.99 & 24.49 & 21.46 & 24.44 \\
\hline \multirow[t]{2}{*}{11} & 21 & 14.49 & 20.95 & 17.50 & 23.22 & 19.34 & 23.38 & 21.58 & 25.38 & 22.16 & 25.34 \\
\hline & 22 & 14.66 & 21.74 & 17.78 & 24.07 & 19.81 & 24.27 & 22.13 & 26.28 & 22.85 & 26.24 \\
\hline \multirow[t]{2}{*}{12} & 23 & 14.80 & 22.51 & 18.02 & 24.91 & 20.24 & 25.16 & 22.65 & 27.18 & 23.52 & 27.14 \\
\hline & 24 & 14.92 & 23.26 & 18.24 & 25.74 & 20.64 & 26.05 & 23.14 & 28.07 & 24.16 & 28.04 \\
\hline \multirow[t]{2}{*}{13} & 25 & 15.02 & 23.99 & 18.42 & 26.56 & 21.00 & 26.93 & 23.60 & 28.96 & 24.78 & 28.94 \\
\hline & 26 & 15.11 & 24.70 & 18.59 & 27.37 & 21.32 & 27.81 & 24.02 & 29.85 & 25.37 & 29.84 \\
\hline \multirow[t]{2}{*}{14} & 27 & 15.18 & 25.39 & 18.73 & 28.17 & 21.60 & 28.68 & 24.41 & 30.74 & 25.92 & 30.75 \\
\hline & 28 & 15.24 & 26.06 & 18.85 & 28.95 & 21.86 & 29.45 & 24.76 & 31.62 & 26.45 & 31.65 \\
\hline \multirow[t]{2}{*}{15} & 29 & 15.28 & 26.71 & 18.95 & 29.72 & 22.09 & 30.32 & 25.08 & 32.50 & 26.94 & 32.55 \\
\hline & 30 & 15.32 & 27.33 & 19.04 & 30.48 & 22.29 & 31.19 & 25.37 & 33.38 & 27.40 & 33.44 \\
\hline \multirow[t]{2}{*}{16} & 31 & 15.36 & 27.94 & 19.12 & 31.21 & 22.46 & 32.04 & 25.64 & 34.25 & 27.83 & 34.34 \\
\hline & 32 & 15.38 & 28.52 & 19.18 & 31.94 & 22.61 & 32.89 & 25.87 & 35.12 & 28.22 & 35.24 \\
\hline \multirow[t]{2}{*}{17} & 33 & 15.41 & 29.08 & 19.23 & 32.65 & 22.74 & 33.72 & 26.08 & 35.98 & 28.58 & 36.13 \\
\hline & 34 & 15.42 & 29.62 & 19.28 & 33.35 & 22.86 & 34.55 & 26.27 & 36.84 & 28.91 & 37.03 \\
\hline 18 & 35 & 15.44 & 30.14 & 19.32 & 34.02 & 22.96 & 35.36 & 26.43 & 37.69 & 29.21 & 37.92 \\
\hline & 36 & 15.45 & 30.64 & 19.35 & 34.68 & 23.04 & 36.16 & 26.58 & 38.54 & 29.48 & 38.81 \\
\hline
\end{tabular}


TABLE 7

(continued)

\begin{tabular}{|c|c|c|c|c|c|c|c|c|c|c|c|}
\hline \multirow{2}{*}{$\begin{array}{l}\text { Years } \\
\text { of } \\
\text { oper- } \\
\text { ation }\end{array}$} & \multirow{2}{*}{$\begin{array}{c}\text { Number } \\
\text { of } \\
\text { draw- } \\
\text { ings }\end{array}$} & \multicolumn{2}{|c|}{ 4-barrel system } & \multicolumn{2}{|c|}{ 5-barrel system } & \multicolumn{2}{|c|}{ 6-barrel system } & \multicolumn{2}{|c|}{ 7-barrel system } & \multicolumn{2}{|c|}{ 8-barrel system } \\
\hline & & $p=0.25$ & $p=0.10$ & $p=0.25$ & $p=0.10$ & $p=0.25$ & $p=0.10$ & $p=0.25$ & $p=0.10$ & $p=0.25$ & $p=0.10$ \\
\hline \multirow[t]{2}{*}{19} & 37 & 15.46 & 31.11 & 19.38 & 35.32 & 23.11 & 36.95 & 26.71 & 39.38 & 29.73 & 39.69 \\
\hline & 38 & 15.47 & 31.57 & 19.40 & 35.93 & 23.18 & 37.73 & 26.82 & 40.21 & 29.95 & 40.57 \\
\hline \multirow[t]{2}{*}{20} & 39 & 15.47 & 32.01 & 19.42 & 36.53 & 23.23 & 38.49 & 26.92 & 41.04 & 30.15 & 41.45 \\
\hline & 40 & 15.48 & 32.43 & 19.43 & 37.12 & 23.27 & 39.24 & 27.00 & 41.85 & 30.32 & 42.33 \\
\hline \multirow[t]{2}{*}{21} & 41 & 15.48 & 32.82 & 19.44 & 37.68 & 23.31 & 39.98 & 27.08 & 42.66 & 30.48 & 43.20 \\
\hline & 42 & 15.49 & 33.20 & 19.45 & 38.23 & 23.34 & 40.70 & 27.13 & 43.45 & 30.61 & 44.06 \\
\hline \multirow[t]{2}{*}{22} & 43 & 15.49 & 33.57 & 19.46 & 38.75 & 23.37 & 41.40 & 27.18 & 44.24 & 30.73 & 44.93 \\
\hline & 44 & 15.49 & 33.91 & 19.47 & 39.26 & 23.39 & 42.09 & 27.23 & 45.02 & 30.84 & 45.78 \\
\hline \multirow[t]{2}{*}{23} & 45 & 15.49 & 34.24 & 19.48 & 39.75 & 23.41 & 42.77 & 27.27 & 45.78 & 30.93 & 46.63 \\
\hline & 46 & 15.50 & 34.55 & 19.48 & 40.23 & 23.43 & 43.42 & 27.31 & 46.54 & 31.01 & 47.47 \\
\hline \multirow[t]{2}{*}{24} & 47 & 15.50 & 34.84 & 19.48 & 40.68 & 23.44 & 44.06 & 27.34 & 47.28 & 31.08 & 48.31 \\
\hline & 48 & 15.50 & 35.12 & 19.49 & 41.12 & 23.45 & 44.69 & 27.36 & 48.01 & 31.14 & 49.14 \\
\hline \multirow[t]{2}{*}{25} & 49 & 15.50 & 35.38 & 19.49 & 41.55 & 23.46 & 45.30 & 27.38 & 48.73 & 31.20 & 49.96 \\
\hline & 50 & 15.50 & 35.64 & 19.49 & 41.95 & 23.47 & 45.89 & 27.40 & 49.43 & 31.24 & 50.77 \\
\hline \multirow[t]{2}{*}{26} & 51 & 15.50 & 35.88 & 19.49 & 42.34 & 23.47 & 46.46 & 27.42 & 50.12 & 31.28 & 51.57 \\
\hline & 52 & 15.50 & 36.10 & 19.49 & 42.71 & 23.48 & 47.02 & 27.43 & 50.80 & 31.32 & 32.36 \\
\hline \multirow[t]{2}{*}{27} & 53 & 15.50 & 36.32 & 19.50 & 43.07 & 23.48 & 47.56 & 27.44 & 51.47 & 31.34 & 53.15 \\
\hline & 54 & 15.50 & 36.52 & 19.50 & 43.41 & 23.49 & 48.09 & 27.45 & 52.12 & 31.37 & 53.92 \\
\hline \multirow[t]{2}{*}{28} & 55 & 15.50 & 36.71 & 19.50 & 43.73 & 23.49 & 48.59 & 27.46 & 52.75 & 31.39 & 54.69 \\
\hline & 56 & & 36.88 & 19.50 & 44.05 & 23.49 & 49.08 & 27.47 & 53.37 & 31.41 & 55.44 \\
\hline \multirow[t]{2}{*}{29} & 57 & & 37.05 & 19.50 & 44.34 & 23.49 & 49.56 & 27.47 & 53.98 & 31.42 & 56.18 \\
\hline & 58 & & 37.21 & 19.50 & 44.63 & 23.49 & 50.01 & 27.48 & 54.57 & 31.43 & 56.91 \\
\hline \multirow[t]{2}{*}{30} & 59 & & 37.36 & 19.50 & 44.90 & 23.50 & 50.46 & 27.48 & 55.15 & 31.45 & 57.63 \\
\hline & 60 & & 37.50 & 19.50 & 45.16 & 23.50 & 50.88 & 27.49 & 55.72 & 31.45 & 58.33 \\
\hline \multirow[t]{2}{*}{31} & 61 & & 37.63 & 19.50 & 45.40 & 23.50 & 51.29 & 27.49 & 56.27 & 31.46 & 59.02 \\
\hline & 62 & & 37.76 & 19.50 & 45.63 & 23.50 & 51.69 & 27.49 & 56.80 & 31.47 & 59.70 \\
\hline \multirow[t]{2}{*}{32} & 63 & & 37.87 & 19.50 & 45.86 & 23.50 & 52.06 & 27.49 & 57.33 & 31.47 & 60.37 \\
\hline & 64 & & 37.98 & 19.50 & 46.07 & 23.50 & 52.43 & 27.50 & 57.84 & 31.48 & 61.02 \\
\hline \multirow[t]{2}{*}{33} & 65 & & 38.08 & 19.50 & 46.27 & 23.50 & 52.78 & 27.50 & 58.33 & 31.48 & 61.66 \\
\hline & 66 & & 38.18 & 19.50 & 46.46 & 23.50 & 53.11 & 27.50 & 58.81 & 31.49 & 62.29 \\
\hline \multirow[t]{2}{*}{34} & 67 & & 38.27 & 19.50 & 46.64 & 23.50 & 53.44 & 27.50 & 59.28 & 31.49 & 62.90 \\
\hline & 68 & & 38.35 & & 46.81 & 23.50 & 53.75 & 27.50 & 59.73 & 31.49 & 63.49 \\
\hline 35 & 69 & & 38.43 & & 46.97 & 23.50 & 54.04 & 27.50 & 60.16 & 31.49 & 64.08 \\
\hline & 70 & & 38.51 & & 47.12 & 23.50 & 54.32 & 27.50 & 60.59 & 31.49 & 64.65 \\
\hline 36 & 71 & & 38.58 & & 47.26 & 23.50 & 54.59 & 27.50 & 61.00 & 31.49 & 65.20 \\
\hline & 72 & & 38.64 & & 47.40 & 23.50 & 54.85 & 27.50 & 61.39 & 31.50 & 65.74 \\
\hline 37 & 73 & & 38.70 & & 47.53 & 23.50 & 55.10 & 27.50 & 61.77 & 31.50 & 66.27 \\
\hline & 74 & & 38.76 & & 47.65 & 23.50 & 55.34 & 27.50 & 62.14 & 31.50 & 66.78 \\
\hline
\end{tabular}


TABLE 7

(concluded)

\begin{tabular}{|c|c|c|c|c|c|c|c|c|c|c|c|}
\hline \multirow{2}{*}{$\begin{array}{c}\text { Years } \\
\text { of } \\
\text { oper- } \\
\text { ation }\end{array}$} & \multirow{2}{*}{$\begin{array}{c}\text { Number } \\
\text { of } \\
\text { draw- } \\
\text { ings }\end{array}$} & \multicolumn{2}{|c|}{ 4-barrel system } & \multicolumn{2}{|c|}{ 5-barrel system } & \multicolumn{2}{|c|}{ 6-barrel system } & \multicolumn{2}{|c|}{ 7-barrel system } & \multicolumn{2}{|c|}{ 8-barrel system } \\
\hline & & $p=0.25$ & $p=0.10$ & $p=0.25$ & $p=0.10$ & $p=0.25$ & $p=0.10$ & $p=0.25$ & $p=0.10$ & $p=0.25$ & $p=0.10$ \\
\hline 38 & $\begin{array}{l}75 \\
76\end{array}$ & & $\begin{array}{l}38.81 \\
38.86\end{array}$ & & $\begin{array}{l}47.77 \\
47.87\end{array}$ & 23.50 & $\begin{array}{l}55.56 \\
55.77\end{array}$ & $\begin{array}{l}27.50 \\
27.50\end{array}$ & $\begin{array}{l}62.50 \\
62.84\end{array}$ & $\begin{array}{l}31.50 \\
31.50\end{array}$ & $\begin{array}{l}67.28 \\
67.77\end{array}$ \\
\hline 39 & $\begin{array}{l}77 \\
78\end{array}$ & & $\begin{array}{l}38.90 \\
38.95\end{array}$ & & $\begin{array}{l}47.98 \\
48.07\end{array}$ & & $\begin{array}{l}55.98 \\
56.17\end{array}$ & $\begin{array}{l}27.50 \\
27.50\end{array}$ & $\begin{array}{l}63.17 \\
63.48\end{array}$ & $\begin{array}{l}31.50 \\
31.50\end{array}$ & $\begin{array}{l}68.24 \\
68.69\end{array}$ \\
\hline 40 & $\begin{array}{l}79 \\
80\end{array}$ & & $\begin{array}{l}38.99 \\
39.02\end{array}$ & & $\begin{array}{l}48.16 \\
48.25\end{array}$ & & $\begin{array}{l}56.36 \\
56.53\end{array}$ & $\begin{array}{l}27.50 \\
27.50\end{array}$ & $\begin{array}{l}63.79 \\
64.08\end{array}$ & $\begin{array}{l}31.50 \\
31.50\end{array}$ & $\begin{array}{l}69.14 \\
69.57\end{array}$ \\
\hline 41 & $\begin{array}{l}81 \\
82\end{array}$ & & $\begin{array}{l}39.06 \\
39.09\end{array}$ & & $\begin{array}{l}48.33 \\
48.41\end{array}$ & & $\begin{array}{l}56.70 \\
56.86\end{array}$ & $\begin{array}{l}27.50 \\
27.50\end{array}$ & $\begin{array}{l}64.36 \\
64.62\end{array}$ & $\begin{array}{r}31.50 \\
31.50\end{array}$ & $\begin{array}{l}69.98 \\
70.39\end{array}$ \\
\hline 42 & $\begin{array}{l}83 \\
84\end{array}$ & & $\begin{array}{l}39.12 \\
39.15\end{array}$ & & $\begin{array}{l}48.48 \\
48.54\end{array}$ & & $\begin{array}{l}57.01 \\
57.15\end{array}$ & & $\begin{array}{l}64.88 \\
65.12\end{array}$ & $\begin{array}{l}31.50 \\
31.50\end{array}$ & $\begin{array}{l}70.78 \\
71.15\end{array}$ \\
\hline 43 & $\begin{array}{l}85 \\
86\end{array}$ & & $\begin{array}{l}39.17 \\
39.20\end{array}$ & & $\begin{array}{l}48.61 \\
48.66\end{array}$ & & $\begin{array}{l}57.29 \\
57.42\end{array}$ & & $\begin{array}{l}65.36 \\
65.58\end{array}$ & $\begin{array}{l}31.50 \\
31.50\end{array}$ & $\begin{array}{l}71.52 \\
71.87\end{array}$ \\
\hline 44 & $\begin{array}{l}87 \\
88\end{array}$ & & $\begin{array}{l}39.22 \\
39.24\end{array}$ & & $\begin{array}{l}48.72 \\
48.77\end{array}$ & & $\begin{array}{l}57.54 \\
57.66\end{array}$ & & $\begin{array}{l}65.79 \\
65.99\end{array}$ & 31.50 & $\begin{array}{l}72.21 \\
72.54\end{array}$ \\
\hline 45 & $\begin{array}{l}89 \\
90\end{array}$ & & $\begin{array}{l}39.26 \\
39.28\end{array}$ & & $\begin{array}{l}48.82 \\
48.87\end{array}$ & & $\begin{array}{l}57.76 \\
57.87\end{array}$ & & $\begin{array}{l}66.19 \\
66.37\end{array}$ & & $\begin{array}{l}72.85 \\
73.16\end{array}$ \\
\hline 46 & $\begin{array}{l}91 \\
92\end{array}$ & & $\begin{array}{l}39.30 \\
39.31\end{array}$ & & $\begin{array}{l}48.91 \\
48.95\end{array}$ & & $\begin{array}{l}57.96 \\
58.06\end{array}$ & & $\begin{array}{l}66.54 \\
66.71\end{array}$ & & $\begin{array}{l}73.45 \\
73.73\end{array}$ \\
\hline 47 & $\begin{array}{l}93 \\
94\end{array}$ & & $\begin{array}{l}39.32 \\
39.34\end{array}$ & & $\begin{array}{l}48.99 \\
49.02\end{array}$ & & $\begin{array}{l}58.14 \\
58.23\end{array}$ & & $\begin{array}{l}66.87 \\
67.02\end{array}$ & & $\begin{array}{l}74.00 \\
74.26\end{array}$ \\
\hline 48 & $\begin{array}{l}95 \\
96\end{array}$ & & $\begin{array}{l}39.35 \\
39.36\end{array}$ & & $\begin{array}{l}49.05 \\
49.08\end{array}$ & & $\begin{array}{l}58.30 \\
58.38\end{array}$ & & $\begin{array}{l}67.16 \\
67.30\end{array}$ & & $\begin{array}{l}74.51 \\
74.75\end{array}$ \\
\hline 49 & $\begin{array}{l}97 \\
98\end{array}$ & & $\begin{array}{l}39.37 \\
39.38\end{array}$ & & $\begin{array}{l}49.11 \\
49.14\end{array}$ & & $\begin{array}{l}58.45 \\
58.51\end{array}$ & & $\begin{array}{l}67.42 \\
67.54\end{array}$ & & $\begin{array}{l}74.98 \\
75.20\end{array}$ \\
\hline 50 & $\begin{array}{r}99 \\
100\end{array}$ & & $\begin{array}{l}39.39 \\
39.40\end{array}$ & & $\begin{array}{l}49.17 \\
49.19\end{array}$ & & $\begin{array}{l}58.57 \\
58.63\end{array}$ & & $\begin{array}{l}67.66 \\
67.77\end{array}$ & & $\begin{array}{l}75.41 \\
75.62\end{array}$ \\
\hline
\end{tabular}

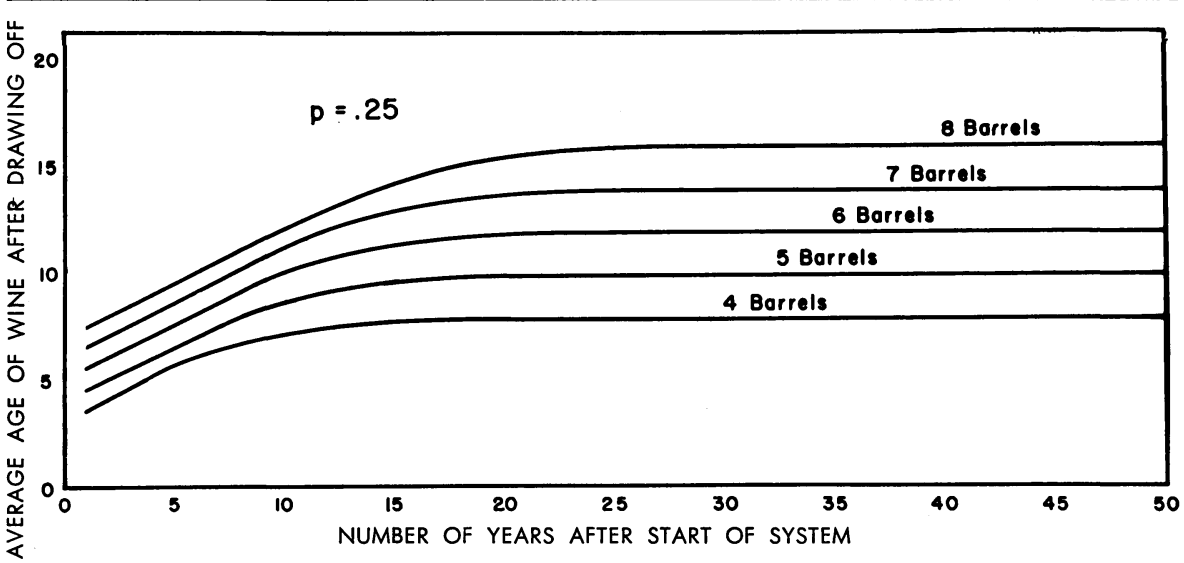

Fig. 6. Average age of wine in the oldest container in 4, 5, 6, 7, and 8-barrel systems when 25 per cent is removed twice a year and the original system is type "B." 
The contents of the barrels at the start of a system that is to be drawn on every six months may not be as young as indicated above. Suppose a system (hereafter called type " $\mathrm{B}$ ") were set up as follows:

\begin{tabular}{|c|c|c|c|c|c|}
\hline \multirow{2}{*}{ Barrel No. } & \multicolumn{5}{|c|}{ Age in number of half-year periods } \\
\hline & $\begin{array}{c}4 \\
\text { barrels }\end{array}$ & $\stackrel{5}{\text { barrels }}$ & $\begin{array}{c}6 \\
\text { barrels }\end{array}$ & $\begin{array}{c}7 \\
\text { barrels }\end{array}$ & $\begin{array}{c}8 \\
\text { barrels }\end{array}$ \\
\hline & 0 & 0 & $\mathbf{0}$ & $\mathbf{0}$ & 0 \\
\hline 2. & 2 & 2 & 2 & 2 & 2 \\
\hline $3 \ldots \ldots \ldots \ldots \ldots$ & 4 & 4 & 4 & 4 & 4 \\
\hline $4 \ldots \ldots \ldots \ldots \ldots$ & 6 & 6 & 6 & 6 & 6 \\
\hline $5 \ldots \ldots \ldots \ldots \ldots$ & & 8 & 8 & 8 & 8 \\
\hline $6 \ldots \ldots \ldots \ldots \ldots$ & & & 10 & 10 & 10 \\
\hline $7 \ldots$. & & & & 12 & 12 \\
\hline $8 \ldots \ldots$ & & & & & 14 \\
\hline
\end{tabular}

In this case the average age at the start is somewhat greater than indicated in the previous example. The average age of the oldest barrel's contents after various periods of aging is given in half-year periods in Table 8, and the data are summarized in Figure 6 for a $p$ of 0.25 and in Figure 7 for a $p$ of 0.10 . While the average age at the start is greater, the curves are very similar to those in Figures 4 and 5. Thus systems may tend to approach the same constant age after many years even though the age at the start may be different.

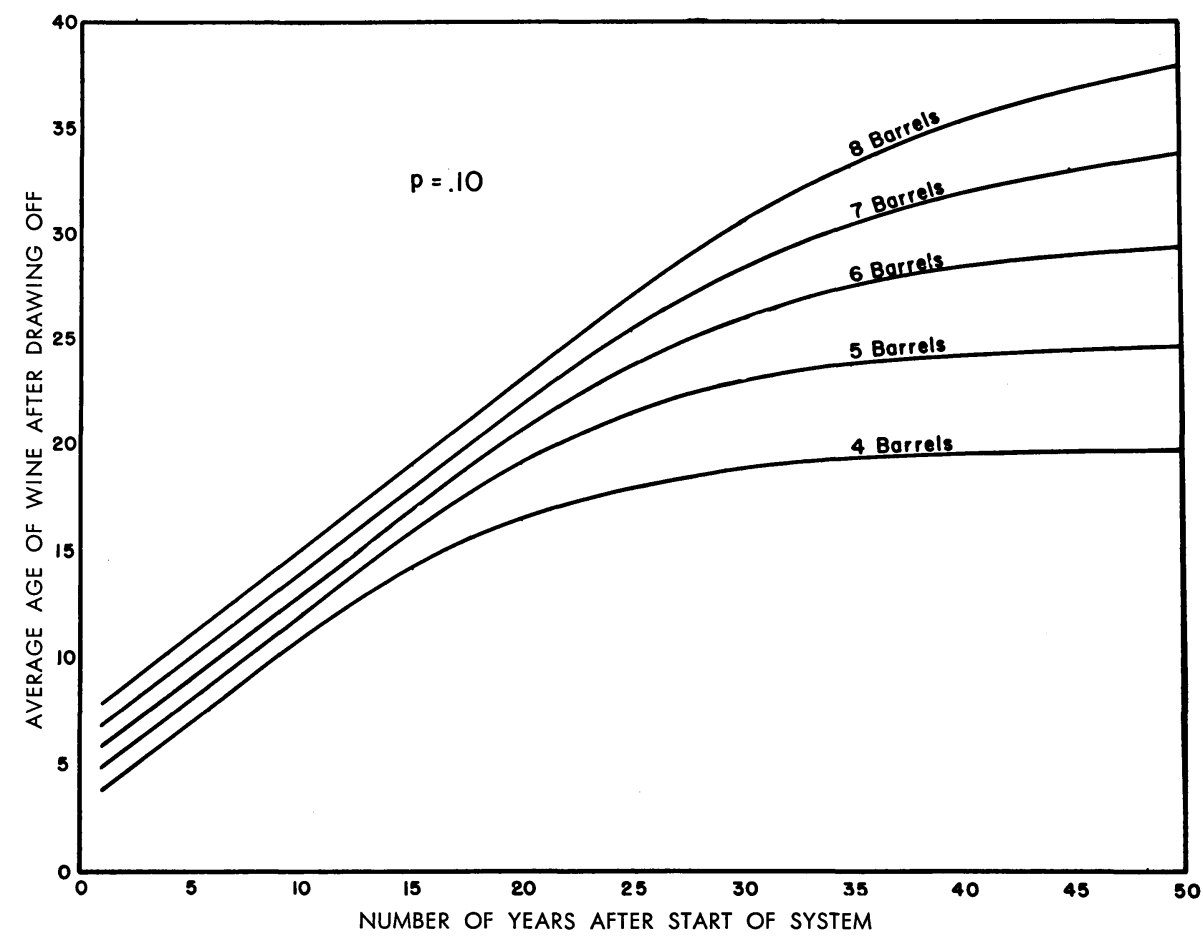

Fig. 7. Average age of wine in the oldest container in 4, 5, 6, 7, and 8-barrel systems when 10 per cent of the wine is removed twice a year and the original system is type "B." 


\section{TABLE 8}

AVERAGE AGE IN HALF YEARS OF THE CONTENTS OF THE LAST BARREL OF CERTAIN SYSTEMS AFTER THE INDICATED NUMBER OF DRAWINGS-OFF AND REPLACEMENTS AT HALF-YEAR INTERVALS. (Type "B")

\begin{tabular}{|c|c|c|c|c|c|c|c|c|c|c|c|}
\hline \multirow{2}{*}{$\begin{array}{l}\text { Years } \\
\text { of } \\
\text { oper- } \\
\text { ation }\end{array}$} & \multirow{2}{*}{$\begin{array}{c}\text { Number } \\
\text { of } \\
\text { draw- } \\
\text { ings }\end{array}$} & \multicolumn{2}{|c|}{ 4-barrel system } & \multicolumn{2}{|c|}{ 5-barrel system } & \multicolumn{2}{|c|}{ 6-barrel system } & \multicolumn{2}{|c|}{ 7-barrel system } & \multicolumn{2}{|c|}{ 8-barrel system } \\
\hline & & $p=0.25$ & $p=0.10$ & $p=0.25$ & $p=0.10$ & $p=0.25$ & $p=0.10$ & $p=0.25$ & $p=0.10$ & $p=0.25$ & $p=0.10$ \\
\hline \multirow[t]{2}{*}{1} & 1 & 6.50 & 6.80 & 8.50 & 8.80 & 10.50 & 10.80 & 12.50 & 12.80 & 14.50 & 14.80 \\
\hline & 2 & 7.00 & 7.60 & 9.00 & 9.60 & 11.00 & 11.60 & 13.00 & 13.60 & 15.00 & 15.60 \\
\hline \multirow[t]{2}{*}{2} & 3 & 7.50 & 8.40 & 9.50 & 10.40 & 11.50 & 12.40 & 13.50 & 14.40 & 15.50 & 16.40 \\
\hline & 4 & 8.01 & 9.20 & 10.00 & 11.20 & 12.00 & 13.20 & 14.00 & 15.20 & 16.00 & 17.20 \\
\hline \multirow[t]{2}{*}{3} & 5 & 8.53 & 10.00 & 10.52 & 12.00 & 12.50 & 14.00 & 14.50 & 16.00 & 16.50 & 18.00 \\
\hline & 6 & 9.05 & 10.80 & 11.01 & 12.80 & 13.00 & 14.80 & 15.00 & 16.80 & 17.00 & 18.80 \\
\hline \multirow[t]{2}{*}{4} & 7 & 9.59 & 11.60 & 11.52 & 13.60 & 13.50 & 15.60 & 15.50 & 17.60 & 17.50 & 19.60 \\
\hline & 8 & 10.12 & 12.41 & 12.03 & 14.40 & 14.01 & 16.40 & 16.00 & 18.40 & 18.00 & 20.40 \\
\hline \multirow[t]{2}{*}{5} & 9 & 10.64 & 13.21 & 12.55 & 15.20 & 14.51 & 17.20 & 16.50 & 19.20 & 18.50 & 21.20 \\
\hline & 10 & 11.15 & 14.01 & 13.07 & 16.00 & 15.03 & 18.00 & 17.01 & 20.00 & 19.00 & 22.00 \\
\hline \multirow[t]{2}{*}{6} & 11 & 11.63 & 14.81 & 13.58 & 16.81 & 15.54 & 18.80 & 17.51 & 20.80 & 19.51 & 22.80 \\
\hline & 12 & 12.08 & 15.60 & 14.08 & 17.62 & 16.07 & 19.60 & 18.02 & 21.60 & 20.02 & 23.60 \\
\hline \multirow[t]{2}{*}{7} & 13 & 12.51 & 16.39 & 14.57 & 18.44 & 16.61 & 20.40 & 18.53 & 22.40 & 20.54 & 24.40 \\
\hline & 14 & 12.89 & 17.18 & 15.04 & 19.27 & 17.14 & 21.20 & 19.04 & 23.20 & 21.05 & 25.20 \\
\hline \multirow[t]{2}{*}{8} & 15 & 13.24 & 17.96 & 15.49 & 20.09 & 17.66 & 22.00 & 19.55 & 24.00 & 21.57 & 26.00 \\
\hline & 16 & 13.56 & 18.74 & 15.91 & 20.91 & 18.16 & 22.80 & 20.05 & 24.80 & 22.10 & 26.80 \\
\hline \multirow[t]{2}{*}{9} & 17 & 13.83 & 19.51 & 16.31 & 21.74 & 18.64 & 23.60 & 20.56 & 25.60 & 22.62 & 27.60 \\
\hline & 18 & 14.08 & 20.26 & 16.68 & 22.56 & 19.10 & 24.40 & 21.05 & 26.40 & 23.13 & 28.40 \\
\hline \multirow[t]{2}{*}{10} & 19 & 14.30 & 21.01 & 17.01 & 23.37 & 19.52 & 25.20 & 21.54 & 27.20 & 23.64 & 29.20 \\
\hline & 20 & 14.48 & 21.75 & 17.32 & 24.19 & 19.93 & 25.99 & 22.01 & 28.00 & 24.15 & 30.00 \\
\hline \multirow[t]{2}{*}{11} & 21 & 14.65 & 22.47 & 17.60 & 25.00 & 20.31 & 26.79 & 22.47 & 28.80 & 24.64 & 30.80 \\
\hline & 22 & 14.78 & 23.18 & 17.85 & 25.80 & 20.65 & 27.58 & 22.90 & 29.60 & 25.12 & 31.60 \\
\hline \multirow[t]{2}{*}{12} & 23 & 14.90 & 23.87 & 18.08 & 26.60 & 20.98 & 28.38 & 23.32 & 30.39 & 25.59 & 32.40 \\
\hline & 24 & 15.00 & 24.55 & 18.28 & 27.39 & 21.27 & 29.17 & 23.72 & 31.19 & 26.04 & 33.20 \\
\hline \multirow[t]{2}{*}{13} & 25 & 15.09 & 25.21 & 18.45 & 28.16 & 21.54 & 29.95 & 24.09 & 31.99 & 26.48 & 34.00 \\
\hline & 26 & 15.16 & 25.86 & 18.61 & 28.93 & 21.78 & 30.74 & 24.44 & 32.78 & 26.89 & 34.80 \\
\hline \multirow[t]{2}{*}{14} & 27 & 15.22 & 26.48 & 18.74 & 29.69 & 22.00 & 31.52 & 24.77 & 33.58 & 27.29 & 35.60 \\
\hline & 28 & 15.27 & 27.09 & 18.85 & 30.43 & 22.20 & 32.29 & 25.06 & 34.37 & 27.66 & 36.40 \\
\hline \multirow[t]{2}{*}{15} & 29 & 15.31 & 27.68 & 18.96 & 31.16 & 22.37 & 33.06 & 25.34 & 35.16 & 28.01 & 37.19 \\
\hline & 30 & 15.35 & 28.26 & 19.04 & 31.88 & 22.52 & 33.82 & 25.59 & 35.95 & 28.34 & 37.99 \\
\hline \multirow[t]{2}{*}{16} & 31 & 15.37 & 28.81 & 19.11 & 32.58 & 22.72 & 34.58 & 25.82 & 36.73 & 28.65 & 38.79 \\
\hline & 32 & 15.40 & 29.34 & 19.18 & 33.27 & 22.87 & 35.33 & 26.02 & 37.52 & 28.93 & 39.58 \\
\hline 17 & 33 & 15.42 & 29.86 & 19.23 & 33.94 & 22.99 & 36.07 & 26.21 & 38.30 & 29.20 & 40.38 \\
\hline & 34 & 15.43 & 30.36 & 19.28 & 34.59 & 23.08 & 36.81 & 26.37 & 39.07 & 29.44 & 41.17 \\
\hline 18 & 35 & 15.45 & 30.83 & 19.31 & 35.23 & 23.15 & 37.53 & 26.52 & 39.84 & 29.66 & 41.97 \\
\hline & 36 & 15.46 & 31.29 & 19.35 & 35.85 & 23.21 & 38.25 & 26.65 & 40.61 & 29.86 & 42.78 \\
\hline 19 & 37 & 15.46 & 31.73 & 19.37 & 36.45 & 23.26 & 38.96 & 26.77 & 41.37 & 30.04 & 43.58 \\
\hline & 38 & 15.47 & 32.15 & 19.39 & 37.03 & 23.30 & 39.65 & 26.87 & 42.13 & 30.20 & 44.39 \\
\hline
\end{tabular}


TABLE 8

(continued)

\begin{tabular}{|c|c|c|c|c|c|c|c|c|c|c|c|}
\hline \multirow{2}{*}{$\begin{array}{l}\text { Years } \\
\text { of } \\
\text { oper- } \\
\text { ation }\end{array}$} & \multirow{2}{*}{$\begin{array}{c}\text { Number } \\
\text { of } \\
\text { draw- } \\
\text { ings }\end{array}$} & \multicolumn{2}{|c|}{ 4-barrel system } & \multicolumn{2}{|c|}{ 5-barrel system } & \multicolumn{2}{|c|}{ 6-barrel system } & \multicolumn{2}{|c|}{ 7-barrel system } & \multicolumn{2}{|c|}{ 8-barrel system } \\
\hline & & $p=0.25$ & $p=0.10$ & $p=0.25$ & $p=0.10$ & $p=0.25$ & $p=0.10$ & $p=0.25$ & $p=0.10$ & $p=0.25$ & $p=0.10$ \\
\hline \multirow[t]{2}{*}{20} & 39 & 15.48 & 32.56 & 19.41 & 37.60 & 23.33 & 40.33 & 26.96 & 42.88 & 30.35 & 45.19 \\
\hline & 40 & 15.48 & 32.94 & 19.43 & 38.15 & 23.36 & 41.01 & 27.04 & 43.62 & 30.48 & 46.00 \\
\hline \multirow[t]{2}{*}{21} & 41 & 15.49 & 33.31 & 19.44 & 38.68 & 23.38 & 41.67 & 27.10 & 44.36 & 30.60 & 46.79 \\
\hline & 42 & 15.49 & 33.66 & 19.45 & 39.19 & 23.40 & 42.32 & 27.16 & 45.09 & 30.71 & 47.59 \\
\hline \multirow[t]{2}{*}{22} & 43 & 15.49 & 34.00 & 19.46 & 39.68 & 23.42 & 42.95 & 27.21 & 45.81 & 30.80 & 48.34 \\
\hline & 44 & 15.49 & 34.32 & 19.47 & 40.16 & 23.43 & 43.57 & 27.26 & 46.52 & 30.89 & 49.15 \\
\hline \multirow[t]{2}{*}{23} & 45 & 15.49 & 34.62 & 19.47 & 40.62 & 23.44 & 44.18 & 27.29 & 47.22 & 30.96 & 49.93 \\
\hline & 46 & 15.50 & 34.91 & 19.48 & 41.06 & 23.45 & 44.77 & 27.33 & 47.91 & 31.03 & 50.69 \\
\hline \multirow[t]{2}{*}{24} & 47 & 15.50 & 35.18 & 19.48 & 41.48 & 23.46 & 45.35 & 27.35 & 48.60 & 31.09 & 51.45 \\
\hline & 48 & 15.50 & 35.44 & 19.49 & 41.89 & 23.47 & 45.92 & 27.38 & 49.27 & 31.14 & 52.20 \\
\hline \multirow[t]{2}{*}{25} & 49 & 15.50 & 35.69 & 19.49 & 42.28 & 23.47 & 46.47 & 27.40 & 49.93 & 31.19 & 52.94 \\
\hline & 50 & 15.50 & 35.92 & 19.49 & 42.66 & 23.48 & 47.00 & 27.41 & 50.58 & 31.23 & 53.67 \\
\hline \multirow[t]{2}{*}{26} & 51 & 15.50 & 36.14 & 19.49 & 43.02 & 23.48 & 47.52 & 27.43 & 51.22 & 31.26 & 54.39 \\
\hline & 52 & 15.50 & 36.35 & 19.49 & 43.36 & 23.48 & 48.03 & 27.44 & 51.85 & 31.30 & 55.10 \\
\hline \multirow[t]{2}{*}{27} & 53 & 15.50 & 36.55 & 19.50 & 43.69 & 23.49 & 48.52 & 27.45 & 52.46 & 31.32 & 55.80 \\
\hline & 54 & 15.50 & 36.73 & 19.50 & 44.00 & 23.49 & 49.00 & 27.46 & 53.07 & 31.35 & 56.50 \\
\hline \multirow[t]{2}{*}{28} & 55 & 15.50 & 36.91 & 19.50 & 44.30 & 23.49 & 49.46 & 27.47 & 53.66 & 31.37 & 57.18 \\
\hline & 56 & 15.50 & 37.08 & 19.50 & 44.59 & 23.49 & 49.91 & 27.47 & 54.23 & 31.39 & 57.85 \\
\hline \multirow[t]{2}{*}{29} & 57 & 15.50 & 37.23 & 19.50 & 44.86 & 23.50 & 50.34 & 27.48 & 54.80 & 31.41 & 58.51 \\
\hline & 58 & 15.50 & 37.38 & 19.50 & 45.12 & 23.50 & 50.76 & 27.48 & 55.35 & 31.42 & 59.16 \\
\hline \multirow[t]{2}{*}{30} & 59 & 15.50 & 37.52 & 19.50 & 45.37 & 23.50 & 51.16 & 27.48 & 55.88 & 31.43 & 59.80 \\
\hline & 60 & 15.50 & 37.65 & 19.50 & 45.60 & 23.50 & 51.55 & 27.49 & 56.40 & 31.44 & 60.43 \\
\hline \multirow[t]{2}{*}{31} & 61 & 15.50 & 37.77 & 19.50 & 45.83 & 23.50 & 51.92 & 27.49 & 56.91 & 31.45 & 61.04 \\
\hline & 62 & 15.50 & 37.89 & 19.50 & 46.04 & 23.50 & 52.28 & 27.49 & 57.40 & 31.46 & 61.65 \\
\hline \multirow[t]{2}{*}{32} & 63 & 15.50 & 37.99 & 19.50 & 46.24 & 23.50 & 52.63 & 27.49 & 57.88 & 31.47 & 62.24 \\
\hline & 64 & & 38.10 & 19.50 & 46.43 & 23.50 & 52.96 & 27.49 & 58.34 & 31.47 & 62.81 \\
\hline \multirow[t]{2}{*}{33} & 65 & & 38.19 & 19.50 & 46.61 & 23.50 & 53.28 & 27.50 & 58.79 & 31.48 & 63.38 \\
\hline & 66 & & 38.28 & 19.50 & 46.78 & 23.50 & 53.59 & 27.50 & 59.22 & 31.48 & 63.94 \\
\hline \multirow[t]{2}{*}{34} & 67 & & 38.36 & 19.50 & 46.94 & 23.50 & 53.89 & 27.50 & 59.64 & 31.48 & 64.48 \\
\hline & 68 & & 38.44 & 19.50 & 47.10 & 23.50 & 54.17 & 27.50 & 60.05 & 31.49 & 65.02 \\
\hline 35 & 69 & & 38.51 & 19.50 & 47.24 & 23.50 & 54.44 & 27.50 & 60.44 & 31.49 & 65.54 \\
\hline & 70 & & 38.58 & 19.50 & 47.38 & 23.50 & 54.70 & 27.50 & 60.82 & 31.49 & 66.05 \\
\hline 36 & 71 & & 38.65 & & 47.51 & 23.50 & 54.95 & 27.50 & 61.19 & 31.49 & 66.54 \\
\hline & 72 & & 38.71 & & 47.63 & 23.50 & 55.19 & 27.50 & 61.54 & 31.49 & 67.02 \\
\hline 37 & 73 & & 38.76 & & 47.75 & 23.50 & 55.42 & 27.50 & 61.89 & 31.50 & 67.50 \\
\hline & 74 & & 38.81 & & 47.86 & 23.50 & 55.63 & 27.50 & 62.22 & 31.50 & 67.95 \\
\hline 38 & 75 & & 38.86 & & 47.96 & 23.50 & 55.84 & 27.50 & 62.53 & 31.50 & 68.40 \\
\hline & 76 & & 38.91 & & 48.06 & & 56.04 & 27.50 & 62.84 & 31.50 & 68.83 \\
\hline 39 & 77 & & 38.95 & & 48.15 & & 56.23 & 27.50 & 63.14 & 31.50 & 69.25 \\
\hline & 78 & & 38.99 & & 48.24 & & 56.41 & 27.50 & 63.42 & 31.50 & 69.66 \\
\hline
\end{tabular}


TABLE 8

(concluded)

\begin{tabular}{|c|c|c|c|c|c|c|c|c|c|c|c|}
\hline \multirow{2}{*}{$\begin{array}{c}\text { Years } \\
\text { of } \\
\text { oper- } \\
\text { ation }\end{array}$} & \multirow{2}{*}{$\begin{array}{c}\text { Number } \\
\text { of } \\
\text { draw- } \\
\text { ings }\end{array}$} & \multicolumn{2}{|c|}{ 4-barrel system } & \multicolumn{2}{|c|}{ 5-barrel system } & \multicolumn{2}{|c|}{ 6-barrel system } & \multicolumn{2}{|c|}{ 7-barrel system } & \multicolumn{2}{|c|}{ 8-barrel system } \\
\hline & & $p=0.25$ & $p=0.10$ & $p=0.25$ & $p=0.10$ & $p=0.25$ & $p=0.10$ & $p=0.25$ & $p=0.10$ & $p=0.25$ & $p=0.10$ \\
\hline 40 & $\begin{array}{l}79 \\
80\end{array}$ & & $\begin{array}{l}39.03 \\
39.06\end{array}$ & & $\begin{array}{l}48.32 \\
48.39\end{array}$ & & $\begin{array}{l}56.58 \\
56.74\end{array}$ & $\begin{array}{l}27.50 \\
27.50\end{array}$ & $\begin{array}{l}63.69 \\
63.96\end{array}$ & $\begin{array}{l}31.50 \\
31.50\end{array}$ & $\begin{array}{l}70.06 \\
70.44\end{array}$ \\
\hline 41 & $\begin{array}{l}81 \\
82\end{array}$ & & $\begin{array}{l}39.09 \\
39.12\end{array}$ & & $\begin{array}{l}48.46 \\
48.53\end{array}$ & & $\begin{array}{l}56.89 \\
57.04\end{array}$ & $\begin{array}{l}27.50 \\
27.50\end{array}$ & $\begin{array}{l}64.21 \\
64.45\end{array}$ & $\begin{array}{l}31.50 \\
31.50\end{array}$ & $\begin{array}{l}70.82 \\
71.18\end{array}$ \\
\hline 42 & $\begin{array}{l}83 \\
84\end{array}$ & & $\begin{array}{l}39.15 \\
39.18\end{array}$ & & $\begin{array}{l}48.59 \\
48.65\end{array}$ & & $\begin{array}{l}57.18 \\
57.31\end{array}$ & $\begin{array}{l}27.50 \\
27.50\end{array}$ & $\begin{array}{l}64.69 \\
64.91\end{array}$ & $\begin{array}{l}31.50 \\
31.50\end{array}$ & $\begin{array}{l}71.53 \\
71.87\end{array}$ \\
\hline 43 & $\begin{array}{l}85 \\
86\end{array}$ & & $\begin{array}{l}39.20 \\
39.22\end{array}$ & & $\begin{array}{l}48.71 \\
48.76\end{array}$ & & $\begin{array}{l}57.44 \\
57.56\end{array}$ & & $\begin{array}{l}65.13 \\
65.34\end{array}$ & $\begin{array}{l}31.50 \\
31.50\end{array}$ & $\begin{array}{l}72.20 \\
72.51\end{array}$ \\
\hline 44 & $\begin{array}{l}87 \\
88\end{array}$ & & $\begin{array}{l}39.24 \\
39.26\end{array}$ & & $\begin{array}{l}48.81 \\
48.86\end{array}$ & & $\begin{array}{l}\mathbf{5 7 . 6 7} \\
\mathbf{5 7 . 7 8}\end{array}$ & & $\begin{array}{l}65.53 \\
65.73\end{array}$ & $\begin{array}{l}31.50 \\
31.50\end{array}$ & $\begin{array}{l}72.82 \\
73.11\end{array}$ \\
\hline 45 & $\begin{array}{l}89 \\
90\end{array}$ & & $\begin{array}{l}39.28 \\
39.30\end{array}$ & & $\begin{array}{l}48.90 \\
48.94\end{array}$ & & $\begin{array}{l}57.88 \\
57.98\end{array}$ & & $\begin{array}{l}65.91 \\
66.08\end{array}$ & & $\begin{array}{l}73.40 \\
73.67\end{array}$ \\
\hline 46 & $\begin{array}{l}91 \\
92\end{array}$ & & $\begin{array}{l}39.31 \\
39.33\end{array}$ & & $\begin{array}{l}48.98 \\
49.01\end{array}$ & & $\begin{array}{l}58.07 \\
58.15\end{array}$ & & $\begin{array}{l}66.25 \\
66.41\end{array}$ & & $\begin{array}{l}73.93 \\
74.19\end{array}$ \\
\hline 47 & $\begin{array}{l}93 \\
94\end{array}$ & & $\begin{array}{l}39.34 \\
39.35\end{array}$ & & $\begin{array}{l}49.05 \\
49.08\end{array}$ & & $\begin{array}{l}58.23 \\
58.31\end{array}$ & & $\begin{array}{l}66.57 \\
66.72\end{array}$ & & $\begin{array}{l}74.43 \\
74.67\end{array}$ \\
\hline 48 & $\begin{array}{l}95 \\
96\end{array}$ & & $\begin{array}{l}39.36 \\
39.37\end{array}$ & & $\begin{array}{l}49.11 \\
49.13\end{array}$ & & $\begin{array}{l}58.38 \\
58.45\end{array}$ & & $\begin{array}{l}66.86 \\
66.99\end{array}$ & & $\begin{array}{l}74.89 \\
75.11\end{array}$ \\
\hline 49 & $\begin{array}{l}97 \\
98\end{array}$ & & $\begin{array}{l}39.38 \\
39.39\end{array}$ & & $\begin{array}{l}49.16 \\
49.18\end{array}$ & & $\begin{array}{l}\mathbf{5 8 . 5 2} \\
58.58\end{array}$ & & $\begin{array}{l}67.12 \\
67.24\end{array}$ & & $\begin{array}{l}75.32 \\
75.52\end{array}$ \\
\hline 50 & $\begin{array}{r}99 \\
100\end{array}$ & & $\begin{array}{l}39.40 \\
39.41\end{array}$ & & $\begin{array}{l}49.20 \\
49.22\end{array}$ & & $\begin{array}{l}58.63 \\
58.69\end{array}$ & & $\begin{array}{l}67.36 \\
67.47\end{array}$ & & $\begin{array}{l}75.71 \\
75.90\end{array}$ \\
\hline
\end{tabular}


From the previous examples, it will be seen that, when 25 per cent is removed twice a year, achievement of a constant age does not occur until after about 10 to 20 years of operation; and the average age varies from 7 years with a 4-barrel system to 15 years with an 8-barrel system. While these periods of operation are feasible, and while such an average age would be desirable for certain types of wines-tawny ports and brandies, for example-yet achieving such a high constant average age does not appear practicable under present management policies. Furthermore, it may not be entirely suitable for wines in which maintaining some fruitiness is desired, such as muscatels and film-yeast unblended sherries. A constant age could be achieved sooner by increasing the per cent drawn each time, as indicated in Table 4, or by increasing the number of drawings per year.

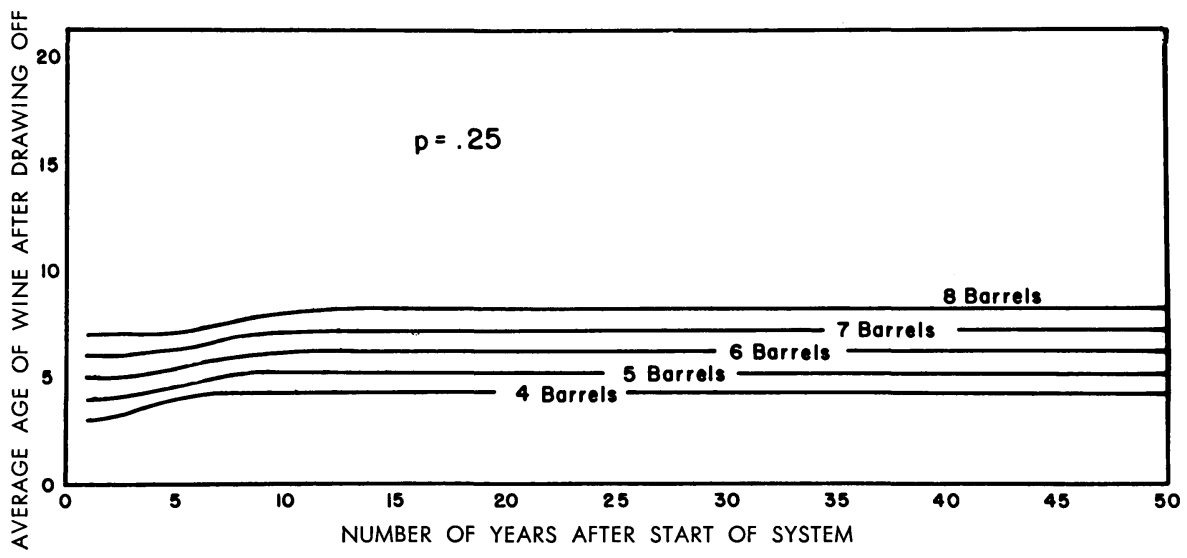

Fig. 8. Average age of the wine in the oldest container for 4, 5, 6, 7, and 8-barrel systems after operation for up to 50 years when 25 per cent of the wine is removed four times a year.

With Quarterly Drawing-off. We give here then a system which is drawn on four times per year. At the start the age of the contents of each barrel, in quarter-year periods, is as follows:

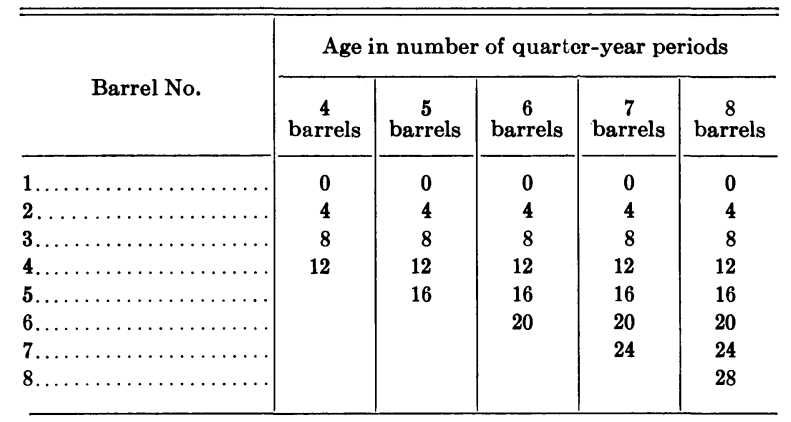

Hereafter this is called fractional-blending system type "C."

Under these conditions the average age in the oldest barrel in quarter-year periods is indicated in Table 9. These data are summarized in Figures 8 and 9 , but the average age is shown in years. Figure 8 shows that when $p$ equals 0.25 
the average age of the contents of the oldest barrel of the 4-barrel system reaches 4 years after 6 years of operation, and is constant at 4.13 years after 11.75 years of operation. That of the 5 -barrel system reaches 5 years after 7.5 years, and is constant at 5.13 after 13.3 years. That of the 6 -barrel system reaches 6 years in 8.7 years, and is constant at 6.13 years after 14.7 years. That of the 7-barrel system reaches 7 years in 9.7 years, and is constant at

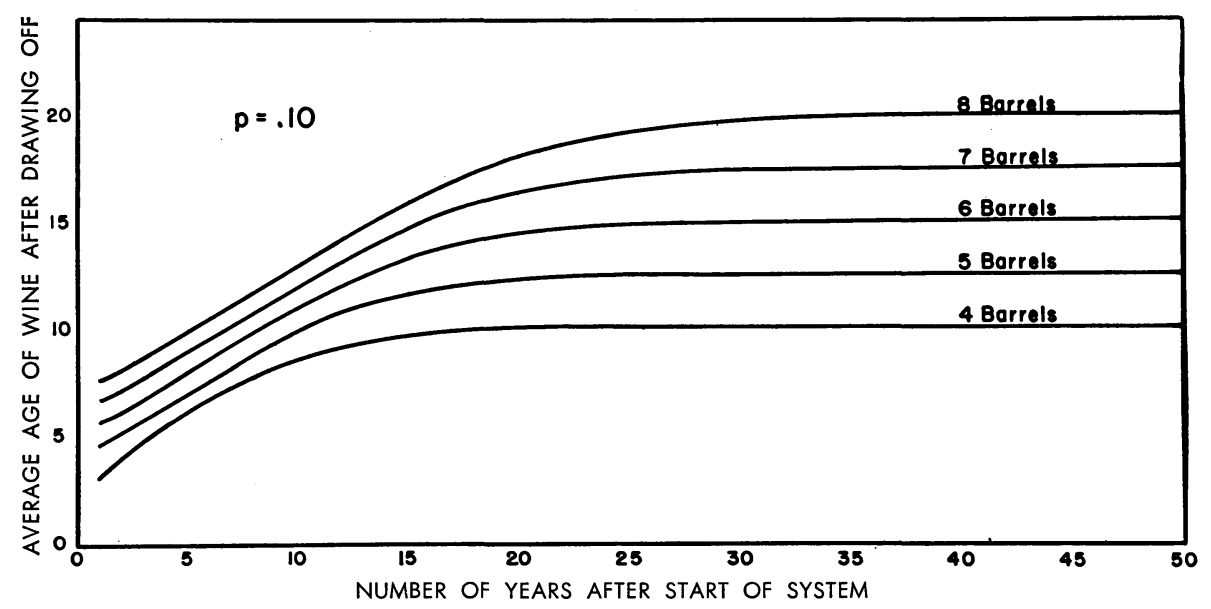

Fig. 9. Average age of the wine in the oldest container for 4, 5, 6, 7, and 8-barrel systems after operation for up to 50 years when 10 per cent of the wine is removed four times a year.

7.13 years after 16.3 years. That of the 8 -barrel system reaches 8 years in 11 years, and is constant at 8.13 after 17.7 years.

Figure 9 summarizes the same data for a $p$ of 0.10 . The average age of the contents of the oldest barrel of the 4-barrel system reaches 10 years in 18.5 years of operation, and is constant at 10.13 years after 32.5 years. That of the 5 -barrel system reaches 12.5 years in 22.5 years, and is constant at 12.63 years after 37 years. That of the 6 -barrel system reaches 15 years in 26 years and is constant at 15.13 years after 41.3 years. That of the 7-barrel system reaches 17.5 years in 29.5 years and is constant at 17.63 years after 45.5 years. That of the 8-barrel system does not reach 20 years until 33 years of operation and does not attain a constant value of 20.13 years until 49.5 years have passed. 
TABLE 9

AVERAGE AGE. IN ONE-QUARTER YEARS OF THE CONTENTS OF THE LAST BARREL OF CERTAIN SYSTEMS AFTER THE INDICATED

NUMBER OF DRAWINGS-OFF AND REPLACEMENTS AT ONE-QUARTER YEAR INTERVALS. (Type "C")

\begin{tabular}{|c|c|c|c|c|c|c|c|c|c|c|c|}
\hline \multirow{2}{*}{$\begin{array}{l}\text { Years } \\
\text { of } \\
\text { oper- } \\
\text { ation }\end{array}$} & \multirow{2}{*}{$\begin{array}{c}\text { Number } \\
\text { of } \\
\text { draw- } \\
\text { ings }\end{array}$} & \multicolumn{2}{|c|}{ 4-barrel system } & \multicolumn{2}{|c|}{ 5-barrel system } & \multicolumn{2}{|c|}{ 6-barrel system } & \multicolumn{2}{|c|}{ 7-barrel system } & \multicolumn{2}{|c|}{ 8-barrel system } \\
\hline & & $p=0.25$ & $p=0.10$ & $p=0.25$ & $p=0.10$ & $p=0.25$ & $p=0.10$ & $p=0.25$ & $p=0.10$ & $p=0.25$ & $p=0.10$ \\
\hline \multirow{4}{*}{1} & 1 & 12.00 & 12.60 & 16.00 & 16.60 & 20.00 & 20.60 & 24.00 & 24.60 & 28.00 & 28.60 \\
\hline & 2 & 12.00 & 13.20 & 16.00 & 17.20 & 20.00 & 21.20 & 24.00 & 25.20 & 28.00 & 29.20 \\
\hline & 3 & 12.00 & 13.80 & 16.00 & 17.80 & 20.00 & 21.80 & 24.00 & 25.80 & 28.00 & 29.80 \\
\hline & 4 & 12.02 & 14.40 & 16.00 & 18.40 & 20.00 & 22.40 & 24.00 & 26.40 & 28.00 & 30.40 \\
\hline \multirow{4}{*}{2} & 5 & 12.07 & 15.00 & 16.00 & 19.00 & 20.00 & 23.00 & 24.00 & 27.00 & 28.00 & 31.00 \\
\hline & 6 & 12.17 & 15.61 & 16.02 & 19.60 & 20.00 & 23.60 & 24.00 & 27.60 & 28.00 & 31.60 \\
\hline & 7 & 12.32 & 16.21 & 16.06 & 20.20 & 20.01 & 24.20 & 24.00 & 28.20 & 28.00 & 32.20 \\
\hline & 8 & 12.52 & 16.82 & 16.12 & 20.80 & 20.02 & 24.80 & 24.00 & 28.80 & 28.00 & 32.80 \\
\hline \multirow{4}{*}{3} & 9 & 12.75 & 17.43 & -16.22 & 21.40 & 20.05 & 25.40 & 24.01 & 29.40 & 28.00 & 33.40 \\
\hline & 10 & 13.02 & 18.05 & 16.36 & 22.01 & 20.09 & 26.00 & 24.02 & 30.00 & 28.00 & 34.00 \\
\hline & 11 & 13.31 & 18.67 & 16.52 & 22.61 & 20.16 & 26.60 & 24.03 & 30.60 & 28.01 & 34.60 \\
\hline & 12 & 13.60 & 19.29 & 16.72 & 23.22 & 20.25 & 27.20 & 24.06 & 31.20 & 28.01 & 35.20 \\
\hline \multirow{4}{*}{4} & 13 & 13.90 & 19.91 & 16.94 & 23.82 & 20.37 & 27.80 & 24.11 & 31.80 & 28.03 & 35.80 \\
\hline & 14 & 14.17 & 20.54 & 17.18 & 24.43 & 20.51 & 28.41 & 24.17 & 32.40 & 28.05 & 36.40 \\
\hline & 15 & 14.44 & 21.16 & 17.42 & 25.04 & 20.68 & 29.01 & 24.26 & 33.00 & 28.08 & 37.00 \\
\hline & 16 & 14.69 & 21.79 & 17.68 & 25.65 & 20.86 & 29.61 & 24.36 & 33.60 & 28.12 & 37.60 \\
\hline \multirow{4}{*}{5} & 17 & 14.92 & 22.41 & 17.93 & 26.27 & 21.07 & 30.22 & 24.49 & 34.20 & 28.18 & 38.20 \\
\hline & 18 & 15.14 & 23.03 & 18.18 & 26.88 & 21.28 & 30.82 & 24.63 & 34.80 & 28.26 & 38.80 \\
\hline & 19 & 15.33 & 23.65 & 18.42 & 27.50 & 21.51 & 31.43 & 24.80 & 35.41 & 28.35 & 39.40 \\
\hline & 20 & 15.50 & 24.26 & 18.65 & 28.11 & 21.74 & 32.03 & 24.97 & 36.01 & 28.46 & 40.00 \\
\hline \multirow{4}{*}{6} & 21 & 15.65 & 24.87 & 18.86 & 28.73 & 21.96 & 32.64 & 25.16 & 36.61 & 28.59 & 40.60 \\
\hline & 22 & 15.78 & 25.46 & 19.06 & 29.34 & 22.19 & 33.25 & 25.36 & 37.21 & 28.73 & 41.20 \\
\hline & 23 & 15.89 & 26.05 & 19.24 & 29.95 & 22.41 & 33.86 & 25.57 & 37.82 & 28.89 & 41.80 \\
\hline & 24 & 15.99 & 26.64 & 19.40 & 30.56 & 22.61 & 34.47 & 25.78 & 38.42 & 29.06 & 42.41 \\
\hline \multirow{4}{*}{7} & 25 & 16.07 & 27.21 & 19.55 & 31.17 & 22.81 & 35.08 & 25.99 & 39.03 & 29.24 & 43.01 \\
\hline & 26 & 16.14 & 27.77 & 19.68 & 31.77 & 22.99 & 35.69 & 26.19 & 39.63 & 29.43 & 43.61 \\
\hline & 27 & 16.21 & 28.32 & 19.80 & 32.37 & 23.17 & 36.30 & 26.39 & 40.24 & 29.62 & 44.21 \\
\hline & 28 & 16.26 & 28.85 & 19.90 & 32.97 & 23.32 & 36.90 & 26.59 & 40.84 & 29.81 & 44.81 \\
\hline \multirow{4}{*}{8} & 29 & 16.30 & 29.37 & 19.99 & 33.56 & 23.47 & 37.51 & 26.77 & 41.45 & 30.01 & 45.42 \\
\hline & 30 & 16.33 & 29.90 & 20.06 & 34.14 & 23.60 & 38.11 & 26.94 & 42.06 & 30.20 & 46.02 \\
\hline & 31 & 16.37 & 30.43 & 20.13 & 34.71 & 23.71 & 38.72 & 27.11 & 42.66 & 30.38 & 46.62 \\
\hline & 32 & 16.39 & 30.96 & 20.19 & 35.29 & 23.82 & 39.32 & 27.26 & 43.27 & 30.57 & 47.23 \\
\hline \multirow{4}{*}{9} & 33 & 16.41 & 31.47 & 20.24 & 35.85 & 23.91 & 39.91 & 27.40 & 43.87 & 30.74 & 47.83 \\
\hline & 34 & 16.43 & 31.97 & 20.28 & 36.41 & 23.99 & 40.51 & 27.53 & 44.48 & 30.90 & 48.44 \\
\hline & 35 & 16.44 & 32.46 & 20.32 & 36.97 & 24.07 & 41.10 & 27.64 & 45.08 & 31.06 & 49.04 \\
\hline & 36 & 16.45 & 32.93 & 20.35 & 37.52 & 24.13 & 41.69 & 27.75 & 45.68 & 31.21 & 49.64 \\
\hline \multirow{4}{*}{10} & 37 & 16.46 & 33.38 & 20.37 & 38.06 & 24.18 & 42.27 & 27.84 & 46.28 & 31.34 & 50.25 \\
\hline & 38 & 16.47 & 33.81 & 20.40 & 38.59 & 24.23 & 42.85 & 27.93 & 46.88 & 31.47 & 50.85 \\
\hline & 39 & 16.48 & 34.22 & 20.41 & 39.11 & 24.27 & 43.42 & 28.00 & 47.48 & 31.58 & 51.45 \\
\hline & 40 & 16.48 & 34.61 & 20.43 & 39.62 & 24.31 & 43.99 & 28.07 & 48.07 & 31.69 & 52.06 \\
\hline \multirow{4}{*}{11} & 41 & 16.48 & 34.99 & 20.44 & 40.12 & 24.34 & 44.55 & 28.13 & 48.66 & 31.78 & 52.66 \\
\hline & 42 & 16.49 & 35.34 & 20.45 & 40.61 & 24.36 & 45.11 & 28.18 & 49.25 & 31.87 & 53.26 \\
\hline & 43 & 16.49 & 35.68 & 20.46 & 41.08 & 24.39 & 45.66 & 28.23 & 49.84 & 31.95 & 53.86 \\
\hline & 44 & 16.49 & 35.99 & 20.47 & 41.54 & 24.40 & 46.20 & 28.27 & 50.42 & 32.02 & 54.46 \\
\hline
\end{tabular}


TABle 9

(continued)

\begin{tabular}{|c|c|c|c|c|c|c|c|c|c|c|c|}
\hline \multirow{2}{*}{$\begin{array}{c}\text { Years } \\
\text { of } \\
\text { oper- } \\
\text { ation }\end{array}$} & \multirow{2}{*}{$\begin{array}{c}\text { Number } \\
\text { of } \\
\text { draw- } \\
\text { ings }\end{array}$} & \multicolumn{2}{|c|}{ 4-barrel system } & \multicolumn{2}{|c|}{5 -barrel system } & \multicolumn{2}{|c|}{ 6-barrel system } & \multicolumn{2}{|c|}{ 7-barrel system } & \multicolumn{2}{|c|}{ 8-barrel system } \\
\hline & & $p=0.25$ & $p=0.10$ & $p=0.25$ & $p=0.10$ & $p=0.25$ & $p=0.10$ & $p=0.25$ & $p=0.10$ & $p=0.25$ & $p=0.10$ \\
\hline \multirow{4}{*}{12} & 45 & 16.49 & 36.29 & 20.47 & 41.99 & 24.42 & 46.74 & 28.30 & 51.00 & 32.08 & 55.05 \\
\hline & 46 & 16.49 & 36.57 & 20.48 & 42.42 & 24.43 & 47.26 & 28.33 & 51.57 & 32.14 & 55.65 \\
\hline & 47 & 16.50 & 36.84 & 20.48 & 42.83 & 24.45 & 47.78 & 28.36 & 52.14 & 32.19 & 56.24 \\
\hline & 48 & 16.50 & 37.08 & 20.49 & 43.23 & 24.45 & 48.28 & 28.38 & 52.71 & 32.23 & 56.83 \\
\hline \multirow{4}{*}{13} & 49 & 16.50 & 37.32 & 20.49 & 43.62 & 24.46 & 48.78 & 28.40 & 53.26 & 32.27 & 57.42 \\
\hline & 50 & 16.50 & 37.53 & 20.49 & 43.99 & 24.47 & 49.26 & 28.41 & 53.81 & 32.30 & 58.00 \\
\hline & 51 & 16.50 & 37.74 & 20.49 & 44.34 & 24.47 & 49.74 & 28.43 & 54.36 & 32.33 & 58.58 \\
\hline & 52 & 16.50 & 37.93 & 20.49 & 44.68 & 24.48 & 50.20 & 28.44 & 54.90 & 32.35 & 59.16 \\
\hline \multirow{4}{*}{14} & 53 & 16.50 & 38.11 & 20.50 & 45.01 & 24.48 & 50.64 & 28.45 & 55.43 & 32.37 & 59.73 \\
\hline & 54 & 16.50 & 38.28 & 20.50 & 45.32 & 24.49 & 51.08 & 28.46 & 55.95 & 32.39 & 60.30 \\
\hline & 55 & 16.50 & 38.43 & 20.50 & 45.61 & 24.49 & 51.50 & 28.47 & 56.46 & 32.41 & 60.87 \\
\hline & 56 & 16.50 & 38.58 & 20.50 & 45.89 & 24.49 & 51.92 & 28.47 & 56.97 & 32.42 & 61.43 \\
\hline \multirow{4}{*}{15} & 57 & 16.50 & 38.71 & 20.50 & 46.16 & 24.49 & 52.31 & 28.48 & 57.46 & 32.44 & 61.98 \\
\hline & 58 & 16.50 & 38.84 & 20.50 & 46.42 & 24.49 & 52.70 & 28.48 & 57.95 & 32.45 & 62.53 \\
\hline & 59 & & 38.96 & 20.50 & 46.66 & 24.50 & 53.07 & 28.48 & 58.42 & 32.45 & 63.07 \\
\hline & 60 & & 39.07 & 20.50 & 46.89 & 24.50 & 53.43 & 28.49 & 58.89 & 32.46 & 63.61 \\
\hline \multirow{4}{*}{16} & 61 & & 39.17 & 20.50 & 47.11 & 24.50 & 53.78 & 28.49 & 59.34 & 32.47 & 64.13 \\
\hline & 62 & & 39.27 & 20.50 & 47.31 & 24.50 & 54.11 & 28.49 & 59.78 & 32.47 & 64.65 \\
\hline & 63 & & 39.36 & 20.50 & 47.51 & 24.50 & 54.43 & 28.49 & 60.22 & 32.48 & 65.17 \\
\hline & 64 & & 39.44 & 20.50 & 47.69 & 24.50 & 54.74 & 28.49 & 60.64 & 32.48 & 65.67 \\
\hline \multirow{4}{*}{17} & 65 & & 39.52 & 20.50 & 47.87 & 24.50 & 55.03 & 28.50 & 61.05 & 32.48 & 66.17 \\
\hline & 66 & & 39.59 & 20.50 & 48.03 & 24.50 & 55.32 & 28.50 & 61.45 & 32.49 & 66.66 \\
\hline & 67 & & 39.65 & 20.50 & 48.19 & 24.50 & 55.59 & 28.50 & 61.83 & 32.49 & 67.14 \\
\hline & 68 & & 39.72 & 20.50 & 48.34 & 24.50 & 55.85 & 28.50 & 62.21 & 32.49 & 67.61 \\
\hline \multirow{4}{*}{18} & 69 & & 39.77 & 20.50 & 48.47 & 24.50 & 56.10 & 28.50 & 62.57 & 32.49 & 68.07 \\
\hline & 70 & & 39.83 & 20.50 & 48.61 & 24.50 & 56.33 & 28.50 & 62.93 & 32.49 & 68.52 \\
\hline & 71 & & 39.88 & 20.50 & 48.73 & 24.50 & 56.56 & 28.50 & 63.27 & 32.50 & 68.96 \\
\hline & 72 & & 39.96 & & 48.85 & 24.50 & 56.78 & 28.50 & 63.60 & 32.50 & 69.39 \\
\hline \multirow{4}{*}{19} & 73 & & 39.96 & & 48.95 & 24.50 & 56.99 & 28.50 & 63.91 & 32.50 & 69.81 \\
\hline & 74 & & 40.00 & & 49.05 & 24.50 & 57.18 & 28.50 & 64.22 & 32.50 & 70.22 \\
\hline & 75 & & 40.04 & & 49.15 & 24.50 & 57.37 & 28.50 & 64.52 & 32.50 & 70.62 \\
\hline & 76 & & 40.08 & & 49.24 & & 57.55 & 28.50 & 64.80 & 32.50 & 71.01 \\
\hline \multirow{4}{*}{20} & 77 & & 40.11 & & 49.32 & & 57.72 & 28.50 & 65.08 & 32.50 & 71.39 \\
\hline & 78 & & 40.14 & & 49.40 & & 57.88 & 28.50 & 65.34 & 32.50 & 71.76 \\
\hline & 79 & & 40.16 & & 49.47 & & 58.03 & 28.50 & 65.59 & 32.50 & 72.12 \\
\hline & 80 & & 40.19 & & 49.54 & & 58.17 & 28.50 & 65.84 & 32.50 & 72.46 \\
\hline \multirow{4}{*}{21} & 81 & & 40.21 & & 49.61 & & 58.31 & & 66.07 & 32.50 & 72.80 \\
\hline & 82 & & 40.23 & & 49.67 & & 58.44 & & 66.30 . & 32.50 & 73.13 \\
\hline & 83 & & 40.25 & & 49.72 & & 58.56 & & 66.51 & 32.50 & 73.44 \\
\hline & 84 & & 40.27 & & 49.78 & & 58.68 & & 66.72 & 32.50 & 73.75 \\
\hline \multirow{4}{*}{22} & 85 & & 40.29 & & 49.83 & & 58.79 & & 66.91 & 32.50 & 74.05 \\
\hline & 86 & & 40.31 & & 49.87 & & 58.89 & & 67.10 & 32.50 & 74.33 \\
\hline & 87 & & 40.32 & & 49.92 & & 58.99 & & 67.28 & 32.50 & 74.61 \\
\hline & 88 & & 40.33 & & 49.96 & & 59.08 & & 67.45 & & 74.87 \\
\hline & 89 & & 40.35 & & 49.99 & & 59.17 & & 67.61 & & 75.13 \\
\hline 23 & 90 & & 40.36 & & 50.03 & & 59.25 & & 67.77 & & 75.38 \\
\hline & 91 & & 40.37 & & 50.06 & & 59.33 & & 67.92 & & 75.62 \\
\hline & 92 & & 40.38 & & 50.09 & & 59.40 & & 68.06 & & 75.85 \\
\hline
\end{tabular}


TABLE 9

(concluded)

\begin{tabular}{|c|c|c|c|c|c|c|c|c|c|c|c|}
\hline \multirow{2}{*}{$\begin{array}{l}\text { Years } \\
\text { of } \\
\text { oper- } \\
\text { ation }\end{array}$} & \multirow{2}{*}{$\begin{array}{c}\text { Number } \\
\text { of } \\
\text { draw- } \\
\text { ings }\end{array}$} & \multicolumn{2}{|c|}{ 4-barrel system } & \multicolumn{2}{|c|}{ 5-barrel system } & \multicolumn{2}{|c|}{ 6-barrel system } & \multicolumn{2}{|c|}{ 7-barrel system } & \multicolumn{2}{|c|}{ 8-barrel system } \\
\hline & & $p=0.25$ & $p=0.10$ & $p=0.25$ & $p=0.10$ & $p=0.25$ & $p=0.10$ & $p=0.25$ & $p=0.10$ & $p=0.25$ & $p=0.10$ \\
\hline 24 & $\begin{array}{l}93 \\
94 \\
95 \\
96\end{array}$ & & $\begin{array}{l}40.39 \\
40.40 \\
40.41 \\
40.41\end{array}$ & & $\begin{array}{l}50.12 \\
50.15 \\
50.17 \\
50.20\end{array}$ & & $\begin{array}{l}59.47 \\
59.54 \\
59.60 \\
59.66\end{array}$ & & $\begin{array}{l}68.19 \\
68.32 \\
68.44 \\
68.56\end{array}$ & & $\begin{array}{l}76.07 \\
76.28 \\
76.49 \\
76.68\end{array}$ \\
\hline 25 & $\begin{array}{r}97 \\
98 \\
99 \\
100\end{array}$ & & $\begin{array}{l}40.42 \\
40.43 \\
40.43 \\
40.44\end{array}$ & & $\begin{array}{l}50.22 \\
50.24 \\
50.26 \\
50.27\end{array}$ & & $\begin{array}{l}59.71 \\
59.76 \\
59.81 \\
59.85\end{array}$ & & $\begin{array}{l}68.67 \\
68.77 \\
68.87 \\
68.97\end{array}$ & & $\begin{array}{l}76.87 \\
77.05 \\
77.22 \\
77.39\end{array}$ \\
\hline 26 & $\begin{array}{l}101 \\
102 \\
103 \\
104\end{array}$ & & $\begin{array}{l}40.44 \\
40.45 \\
40.45 \\
40.45\end{array}$ & & $\begin{array}{l}50.29 \\
50.31 \\
50.32 \\
50.33\end{array}$ & & $\begin{array}{l}59.90 \\
59.94 \\
59.97 \\
60.01\end{array}$ & & $\begin{array}{l}69.05 \\
69.14 \\
69.22 \\
69.29\end{array}$ & & $\begin{array}{l}77.55 \\
77.70 \\
77.84 \\
77.98\end{array}$ \\
\hline 27 & $\begin{array}{l}105 \\
106 \\
107 \\
108\end{array}$ & & $\begin{array}{l}40.46 \\
40.46 \\
40.46 \\
40.47\end{array}$ & & $\begin{array}{l}50.35 \\
50.36 \\
50.37 \\
50.38\end{array}$ & & $\begin{array}{l}60.04 \\
60.07 \\
60.10 \\
60.13\end{array}$ & . & $\begin{array}{l}69.36 \\
69.43 \\
69.50 \\
69.56\end{array}$ & & $\begin{array}{l}78.11 \\
78.24 \\
78.35 \\
78.47\end{array}$ \\
\hline 28 & $\begin{array}{l}109 \\
110 \\
111 \\
112\end{array}$ & & $\begin{array}{l}40.47 \\
40.47 \\
40.47 \\
40.48\end{array}$ & & $\begin{array}{l}50.39 \\
50.39 \\
50.40 \\
50.41\end{array}$ & & $\begin{array}{l}60.15 \\
60.17 \\
60.20 \\
60.22\end{array}$ & & $\begin{array}{l}69.61 \\
69.67 \\
69.72 \\
69.77\end{array}$ & & $\begin{array}{l}78.58 \\
78.68 \\
78.78 \\
78.87\end{array}$ \\
\hline 29 & $\begin{array}{l}113 \\
114 \\
115 \\
116\end{array}$ & & $\begin{array}{l}40.48 \\
40.48 \\
40.48 \\
40.48\end{array}$ & & $\begin{array}{l}50.42 \\
50.42 \\
50.43 \\
50.43\end{array}$ & & $\begin{array}{l}60.24 \\
60.25 \\
60.27 \\
60.29\end{array}$ & & $\begin{array}{l}69.81 \\
69.85 \\
69.90 \\
69.93\end{array}$ & & $\begin{array}{l}78.96 \\
79.05 \\
79.13 \\
79.20\end{array}$ \\
\hline 30 & $\begin{array}{l}117 \\
118 \\
119 \\
120\end{array}$ & & $\begin{array}{l}40.48 \\
40.49 \\
40.49 \\
40.49\end{array}$ & & $\begin{array}{l}50.44 \\
50.44 \\
50.45 \\
50.45\end{array}$ & & $\begin{array}{l}60.30 \\
60.31 \\
60.33 \\
60.34\end{array}$ & & $\begin{array}{l}69.97 \\
70.00 \\
70.03 \\
70.06\end{array}$ & & $\begin{array}{l}79.28 \\
79.35 \\
79.41 \\
79.47\end{array}$ \\
\hline 31 & $\begin{array}{l}121 \\
122 \\
123 \\
124\end{array}$ & & $\begin{array}{l}40.49 \\
40.49 \\
40.49 \\
40.49\end{array}$ & & $\begin{array}{l}50.45 \\
50.46 \\
50.46 \\
50.46\end{array}$ & & $\begin{array}{l}60.35 \\
60.36 \\
60.37 \\
60.38\end{array}$ & & $\begin{array}{l}70.09 \\
70.12 \\
70.14 \\
70.16\end{array}$ & & $\begin{array}{l}79.53 \\
79.59 \\
79.64 \\
79.69\end{array}$ \\
\hline 32 & 125 & & 40.49 & & 50.47 & & 60.39 & & 70.18 & & 79.74 \\
\hline 33 & 130 & & 40.50 & & 50.48 & & 60.42 & & 70.27 & & 79.94 \\
\hline 34 & 135 & & 40.50 & & 50.49 & & 60.45 & & 70.34 & & 80.09 \\
\hline 35 & 140 & & 40.50 & & 50.49 & & 60.46 & & 70.39 & & 80.20 \\
\hline 37 & 145 & & 40.50 & & 50.49 & & 60.48 & & 70.42 & & 80.28 \\
\hline 38 & 150 & & & & 50.50 & & 60.48 & & 70.44 & & 80.34 \\
\hline 40 & 160 & & & & & & 60.49 & & 70.47 & & 80.42 \\
\hline 43 & 170 & & & & & & 60.50 & & 70.49 & & 80.46 \\
\hline 45 & 180 & & & & & & & & 70.49 & & 80.48 \\
\hline 48 & 190 & & & & & & & & 70.50 & & 80.49 \\
\hline 50 & 200 & & & & & & & & & & 80.50 \\
\hline
\end{tabular}




\section{DISCUSSION}

Sometimes the wine sold from a fractional-blending system is labeled to indicate the age of the oldest wine in the mixture. This is, of course, very misleading. For instance, with an 8-barrel system that is drawn on once a year, where $p$ equals 0.25 , at the end of 30 years of operation the average age of the

TABLE 10

SUMMARY OF FRACTIONAL-BLENDING SYSTEMS

Maximum Average Age Attainable and Number of Years Necessary to Reach 90 Per Cent of the Maximum Age for Several Systems and Percentages of Withdrawal

\begin{tabular}{|c|c|c|c|c|c|c|}
\hline \multirow[b]{2}{*}{ System } & \multicolumn{2}{|c|}{$p=0.10$} & \multicolumn{2}{|c|}{$p=0.25$} & \multicolumn{2}{|c|}{$p=0.50$} \\
\hline & $\begin{array}{l}\text { Maximum } \\
\text { av. age, } \\
\text { years }\end{array}$ & $\begin{array}{c}\text { Years } \\
\text { (approx.) } \\
\text { to reach } \\
90 \% \text { of } \max . \\
\text { av. age }\end{array}$ & $\begin{array}{l}\text { Maximum } \\
\text { av. age, } \\
\text { years }\end{array}$ & $\begin{array}{c}\text { Years } \\
\text { (approx.) } \\
\text { to reach } \\
90 \% \text { of max. } \\
\text { av. age }\end{array}$ & $\begin{array}{l}\text { Maximum } \\
\text { av. age, } \\
\text { years }\end{array}$ & $\begin{array}{c}\text { Years } \\
\text { (approx.) } \\
\text { to reach } \\
90 \% \text { of max. } \\
\text { av. age }\end{array}$ \\
\hline 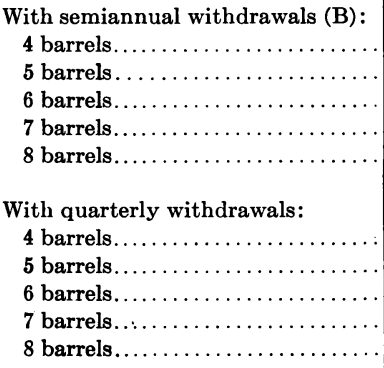 & $\begin{array}{l}19.75 \\
24.75 \\
29.75 \\
34.75 \\
39.75\end{array}$ & $\begin{array}{l}24.0 \\
27.0 \\
33.0 \\
37.5 \\
41.5 \\
\\
\\
11.50 \\
13.50 \\
15.75 \\
18.00 \\
20.00\end{array}$ & $\begin{array}{r}7.75 \\
9.75 \\
11.75 \\
13.75 \\
15.75 \\
\\
\\
4.125 \\
5.125 \\
6.125 \\
7.125 \\
8.125\end{array}$ & $\begin{array}{r}8.5 \\
10.5 \\
12.0 \\
13.5 \\
15.0 \\
\\
\\
4.25 \\
4.75 \\
5.50 \\
5.75 \\
6.25\end{array}$ & & \\
\hline
\end{tabular}

wine drawn off is about 10 years less than the age of the system. When $p$ is 0.10 the average age in the last barrel is about 34 years, whereas the oldest wine is 38 years old after 30 years of operation. Even greater differences exist when the system is drawn on four times a year. When $p$ is 0.25 and the system is drawn on four times a year, a constant age of 4.13 years is soon reached. Even if this system is continued for 50 years, the average age of the product withdrawn from the oldest container will not exceed this figure. It is obviously false to advertise the product of such a blending system with the date of its establishment. It is true that there will be a minuscule amount of the wine placed in the original barrels still in the oldest container, but the aver- 
age age of the product withdrawn will never exceed 4.13 years. The practical advantages of the fractional-blending systems for maintaining a product of a certain age are clearly indicated in the four-times-a-year withdrawal system.

The capacity of a fractional-blending system to maintain wine of a certain standard character should not be exaggerated. If the quality and character of the entering wine are changed, the quality and character of the product withdrawn will eventually change, but they will change slowly; and a deviation during a single year will have only a slight influence on the product if the original quality and character are restored in the next wine added.

Some restrictions on the size of containers used may need to be applied. Amerine (1950) has emphasized that the rate of aging in wooden containers is partially a function of the ratio of surface to volume. Aging is much slower in a very large container (of 10,000 to 50,000 gallons, for example) where only a small amount of surface is exposed per unit volume, as compared with that achieved in a small container (of 50 to 500 gallons). The actual age of the wine in a system consisting of 50,000-gallon containers will be the same as that in a system of 100-gallon containers, but the apparent age will be much greater in the latter case.

A summary of the various fractional-blending systems with respect to maximum average age attainable and number of years necessary to attain 90 per cent of the maximum age is given in Table 10. This table may serve as a guide in selecting a fractional-blending system to achieve a specific purpose.

\section{ACKNOWLEDGMENT}

The authors are indebted to Mrs. Marian Murray, Statistician, who computed and checked the numerical tables.

\section{LITERATURE CITED}

Amerine, Maynard A.

1950. The response of wine to aging. Wines and Vines $31(3): 19-22 ;(4): 71-74 ;(5)$ : 28-31.

Baker, G. A., M. A. Amerine, and E. B. Roessler

1951. Fractional blending systems for aging alcoholic beverages. Food Technology 5(7): 304-5.

Cruess, W. V.

1948. Investigations of the flor sherry process. California Agricultural Experiment Station Bulletin $710: 1-40$.

GonzÁlez GoRdon, MANUEl M.a

1935. Jerez-Xerez-"Scheris." Imprenta A. Padura, Jerez de la Frontera, Spain. 405 p. (See especially p. 267 et seq.)

1948. Jerez-Xerez-Scheris. Jerez Industrial, S.A., Jerez de la Frontera, Spain. 605 p. (See especially p. 329 et seq.) 

The journal Hilgardia is published at irregular intervals, in volumes of about 600 pages. The number of issues per volume varies.

Subscriptions are not sold. The periodical is sent as published only to libraries, or to institutions in foreign countries having publications to offer in exchange.

You may obtain a single copy of any issue free, as long as the supply lasts; please request by volume and issue number from:

\section{Publications Office \\ College of Agriculture \\ Berkeley 4, California}

The limit to nonresidents of California is 10 separate issues on a single order. A list of the issues still available will be sent on request. 